\title{
Visible-Light-Active Noble-Metal Photocatalysts for Water Disinfection: A Review
}

\author{
Ashraya Upadhyaya, Guillermo Rincón* \\ Department of Civil and Environmental Engineering, University of New Orleans, New Orleans, USA \\ Email: aupadhya@uno.edu, „gjrincon@uno.edu
}

How to cite this paper: Upadhyaya, A. and Rincón, G. (2019) Visible-Light-Active Noble-Metal Photocatalysts for Water Disinfection: A Review. Journal of Water Resource and Protection, 11, 1207-1232. https://doi.org/10.4236/jwarp.2019.1110070

Received: July 25, 2019

Accepted: October 6, 2019

Published: October 9, 2019

Copyright $\odot 2019$ by author(s) and Scientific Research Publishing Inc. This work is licensed under the Creative Commons Attribution International License (CC BY 4.0).

http://creativecommons.org/licenses/by/4.0/

\section{cc (i) Open Access}

\begin{abstract}
The sanitary and environmental challenges posed by an ever growing economically and geographically diverse human population include the need for sustainable, inexpensive, scalable, and decentralized water treatment technologies that can supplement or replace conventional treatment methods. These challenges can be met by semiconductor photocatalysis, especially if the process is driven by visible light energy. Visible-light active (VLA) photocatalysis, as opposed to traditional energy-intensive and chemically driven disinfection methods such as ozonation, UV irradiation and chlorination, has the potential for achieving high disinfection efficiency with low energy consumption and no harmful by-products. This technology generates in-situ reactive oxygen species (ROS) such as $\mathrm{H}_{2} \mathrm{O}_{2}, \mathrm{OH}^{\cdot}$ and $\mathrm{O}_{2}^{--}$, without the need for chemicals addition. In turn, ROS are capable of penetrating cell walls and membranes of microorganisms, effectively inactivating them. Although multiple types of VLA photocatalysts have been used experimentally for disinfection of water, noble-metal-based photocatalysts have gained the most interest due to their surface plasma resonance (SPR) effect, which acts synergistically to increase the disinfection potential of the photocatalytic process. This paper is a review of the different types of noble-metal-based VLA photocatalysts used for water disinfection in different experimental settings, their synthesis procedures and disinfection mechanisms. It also discusses innovative approaches to overcome a major hurdle in photocatalysis, that is, the rapid recombination of the electron and hole pair, by including specific dopants into the structure of the photocatalyst.
\end{abstract}

\section{Keywords}

Photocatalytic Disinfection, Visible Light Active (VLA) Photocatalysis, Noble Metal, Reactive Oxidative Species (ROS) 


\section{Introduction}

Waterborne diseases have had a detrimental impact on human civilization throughout history. These illnesses became especially apparent once people started congregating in confined urbanized spaces after the industrial revolution. In the 19th century, unmanaged sanitary systems led to disease outbreaks such as those of cholera and typhoid in the UK and the USA, respectively. Following these events, doctors and scientists concluded that harmful pathogens in water, rather than the previously assumed "miasma" or "foul smell" of the city, were the cause of such diseases [1] [2]. Improvement in public sanitation and hygiene, especially the implementation of water disinfection through chlorination, gained attention after this discovery [3] and has since played a fundamental role in the control of pathogens detrimental to human health.

A century and a half after these water-borne epidemics, many developing nations still lack proper water disinfecting systems. Water disinfection is the process of removing, deactivating or killing pathogenic microorganisms. In 2015, the World Health Organization (WHO) reported that about $80 \%$ of the developing world population still suffers from illnesses resulting from poor water quality and sanitation [4]. Today, 844 million people have no access to basic drinking water services, and at least 2 billion people use a drinking water source contaminated with feces. It is estimated that there are half a million deaths each year from diarrheal diseases caused by bacteria such as Escherichia coli, Salmonella $s p$. and Cholera sp., parasites and viral pathogens [4]. Therefore, there is an immediate need to develop efficient, sustainable and scalable water disinfection systems to satisfy the necessities of small communities that lack access to safe drinking water.

Currently, most water treatment facilities use either chemical or physical methods of disinfection. Common chemical disinfectants include chlorine, sodium hypochlorite, chlorine dioxide, and ozone, which rely on their oxidative and residual power to kill microorganisms and impede recontamination. Chlorination, while highly effective in killing bacteria and viruses, does not eliminate protozoa, including Cryptosporidium, Giardia and Acanthamoeba [5]. Other drawbacks of chlorination include the toxic effects of residual chlorine to aquatic life, and unwanted secondary reactions with natural organic matter in water to form carcinogenic and mutagenic disinfection byproducts (DBPs). There are also hazards in producing, transporting and handling large amounts of such chemicals. Physical disinfection processes such as UV radiation and membrane filtration are also effective in removing pathogens from water, but their application is expensive, and lacks the residual disinfecting effect, being only effective around the contact site.

Photocatalysis is a promising alternative technique for water purification. Photocatalysis is a process in which a semiconductor catalyst facilitates and speeds up a process using energy from a light source, traditionally sunlight. This harvesting and usage of solar energy by a photocatalyst is extremely versatile. Photocatalysts are expected to play a significant role in addressing the challenges 
of the $21^{\text {st }}$ century. From disinfection to energy shortage, environmental pollution and global warming, photocatalysts will be a key technological apparatus moving forward.

In general, photocatalysts can either oxidize and/or reduce a given compound into other compounds or elements without the photocatalyst itself being consumed. They can also split water to produce hydrogen gas, a pollutant free fuel source [6] [7]. They can reduce $\mathrm{CO}_{2}$ content from the atmosphere by converting it to alkanes [8]. Most importantly, photocatalysts can also kill pathogens by producing highly oxidizing chemical species including, but not limited to, the hydroxyl radical [9] [10] [11] [12] [13].

However, traditional $\mathrm{TiO}_{2}$-based photocatalysts require $\mathrm{UV}$ rays $(\lambda<380 \mathrm{~nm})$ to operate, because their band gap is greater than $3 \mathrm{eV}$ (for example, $3.2 \mathrm{eV}$ for anatase $\mathrm{TiO}_{2}$ ) [14]. They can only utilize about $4 \%$ of the natural sun light, unable to take advantage of the $43 \%$ visible light energy in the solar spectrum [15]. This poses a challenge, that is, to produce photocatalysts that can effectively work under visible light wavelengths, also known as visible-light-active (VLA) photocatalysts.

VLA photocatalytic disinfection is a non-conventional technique that can be scalable and useful in decentralized water and wastewater treatment systems. This system employs photocatalysts that are capable of absorbing photons in the visible light spectrum (380 $\mathrm{nm}$ or larger), which include a portion of the sunlight reaching Earth surface, and artificial light. One technique that has been proven effective in the synthesis of VLA photocatalysts consists in the addition of noble metal nanoparticles (NPs) onto suitable semiconductors, such as $\mathrm{AgCl}$ and $\mathrm{AgBr}$, to form a metal-semiconductor composite photocatalyst [16]. Noble metal NPs such as Ag, Au, Pt can strongly absorb visible light [17]-[23] due to their surface plasmon resonance (SPR), which can be accessed by varying the size, shape and surrounding medium of the metal NP [24]-[33]. Moreover, noble metal NPs can also work as electron traps and active reaction sites [33] [34] [35].

To date, research has been focused on developing applications of photocatalytic systems to water treatment. This paper presents a review of the mechanism involved in semiconductor photocatalysis, and examines wavelength utilization for bandgap reduction and other roles played by photocatalysts doped with noble metals NPs in VLA photocatalytic disinfection. A summary of most recently developed VLA photocatalysts, their synthesis methods, and disinfection efficiencies is also included as part of this review.

\section{Photocatalytic Disinfection}

\subsection{Photocatalytic Mechanism Overview}

The most commonly studied and generally accepted mechanism of photocatalysis involves the use of titanium dioxide $\left(\mathrm{TiO}_{2}\right)$ in the oxidation of organic pollutants and inactivation of pathogens. Figure 1 shows the mechanism of pollutant oxidation by $\mathrm{TiO}_{2}$. 


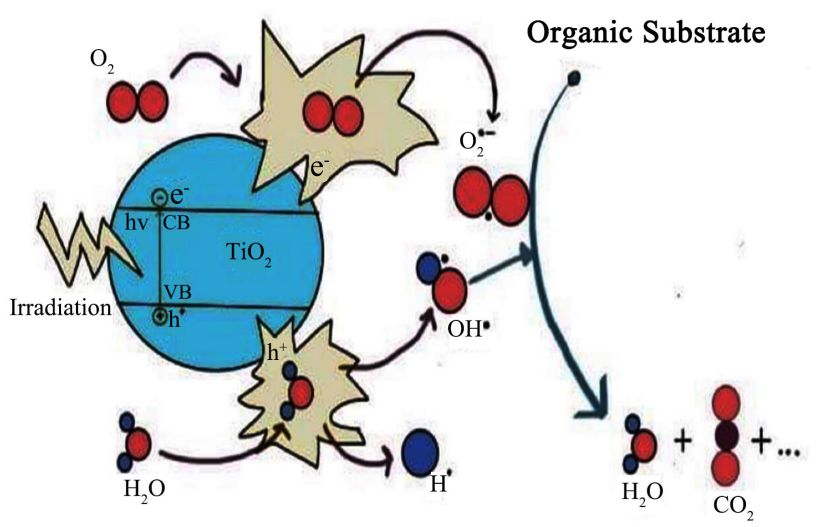

Figure 1. Mechanism of photocatalytic oxidation of organic substrates [36].

When photons of enough energy reach the $\mathrm{TiO}_{2}$ surface, an electron is ejected from the valence band (VB) to the conduction band (CB) of the semiconductor, as described by the following reactions:

$$
\begin{gathered}
\mathrm{TiO}_{2}+\mathrm{hv} \rightarrow \mathrm{e}_{\mathrm{CB}}^{-}+\mathrm{h}_{\mathrm{VB}}^{+} \\
\mathrm{e}^{-}+\mathrm{O}_{2} \rightarrow \mathrm{O}_{2}^{--}, \\
\mathrm{h}^{+}+\mathrm{H}_{2} \mathrm{O} \rightarrow \mathrm{OH}^{\cdot}+\mathrm{H}^{+} \\
\mathrm{h}^{+}\left(\text {or } \mathrm{OH}^{-}\right)+\text {organic substrate } \rightarrow \text { oxidized organic substrate }
\end{gathered}
$$

The difference in energy between the VB and the $\mathrm{CB}$ is known as the bandgap, a region within which an electron cannot remain stable. The electron jump caused by the influx of additional energy leads to the formation of an electron-hole pair $\left(\mathrm{e}^{-}\right.$and $\left.\mathrm{h}^{+}\right)$. The ability of an electron to make this jump at an optimum rate is unique to semiconductors and this property is exploited in photocatalysis.

Once the electron-hole pair forms, these photo-generated charges will migrate onto the surface of the photocatalyst and undergo a variety of complex reactions to produce reactive oxidative species (ROS) such as the hydroxyl radical $\left(\mathrm{OH}^{*}\right)$, hydrogen peroxide $\left(\mathrm{H}_{2} \mathrm{O}_{2}\right)$, and the superoxide ion $\left(\mathrm{O}_{2}^{--}\right)$, which are capable of both oxidizing dissolved organics and inactivating pathogens [37].

While effective, conventional $\mathrm{TiO}_{2}$ is not capable of VLA photocatalysis without a change in its morphology. The limitation of this process with $\mathrm{TiO}_{2}$ lies in the need for an energy input higher than $3.2 \mathrm{eV}$, equivalent to a wavelength shorter than $390 \mathrm{~nm}$ (high frequency waves such as UVB and UVC) to effectively excite and eject electrons, rendering the process energy-intensive. If solar light were to be used, the process would be inefficient since the Earth surface receives $8 \%$ UV rays, of which $0.5 \%, 4.5 \%$ and $95 \%$ correspond to the UVC, UVB and UVA spectrum, respectively [38]. To overcome this limitation, modifications to the $\mathrm{TiO}_{2}$ lattice, consisting of doping its structure with either a metal or a non-metal, are necessary to reduce the bandgap width, enable electron-hole pair formation by visible light energy, and prevent recombination of the formed electron-hole pair. 


\subsection{Photocatalysis for Water Disinfection}

Typically, when a photocatalyst is used for disinfection, the electron-hole pair forms from the application of photons of enough energy. Some pairs become unstable and the electron drops from the $\mathrm{CB}$ back into the VB leading to recombination and the release of energy as heat [39] [40]. The pairs that remain stable migrate to the surface of the photocatalyst.

The $\mathrm{OH}^{-}$ions in the aqueous solution that are adsorbed onto the $\mathrm{TiO}_{2}$ surface react with the migrated $\mathrm{h}^{+}$to form the adsorbed hydroxyl ion $\left(\mathrm{OH}_{\text {absorbed }}\right)$ [41] [42] [43]. If other electron donors (reductants) are present in the solution, the $\mathrm{h}^{+}$may also directly gain electrons from these reductants and become oxidized. Therefore, the $\mathrm{h}^{+}$acts as an electron acceptor, directly oxidizing the organic substance that donates said electron. If sufficient reductants are present, the $\mathrm{OH}_{\text {absorbed }}^{\cdot}$ is readily released into the bulk solution to form the $\mathrm{OH}_{\text {bulk }}^{*}$, which plays an important role in the inactivation/destruction of microorganisms [44]. Also, two $\mathrm{OH}_{\text {bulk }}^{\cdot}$ radicals can combine with each other in solution to form $\mathrm{H}_{2} \mathrm{O}_{2}$, which is also an effective disinfectant [45] [46] [47].

On the other hand, the surface migrated $\mathrm{e}^{-}$react with electron acceptors (oxidants). Generally, they react with dissolved oxygen in the water to form the superoxide ion $\left(\mathrm{O}_{2}^{--}\right)$[48] [49]. Electrons may also react with the $\mathrm{H}_{2} \mathrm{O}_{2}$ formed via the interactions mentioned above to produce $\mathrm{OH}_{\text {bulk }}^{\cdot}$. The formation of $\left(\mathrm{O}_{2}^{--}\right)$ helps disinfection by gaining the electron from the $\mathrm{e}^{-}$and $\mathrm{h}^{+}$pair, delaying and even preventing recombination at the below surface level, as electrons that have moved up the surface are being scavenged. The superoxide ion is a strong oxidant capable of inactivating pathogens [50].

As previously mentioned, generated $\mathrm{ROS}\left(\mathrm{OH}^{\cdot}, \mathrm{H}_{2} \mathrm{O}_{2}, \mathrm{O}_{2}^{--}\right)$attack microbes in water, which results in their destruction or inactivation [51]. The proposed action mechanism suggests that these ROS begin by systematically destabilizing or disorienting the outer membrane or cell wall of the microorganism. Then, they proceed to penetrate it, destroying the inner cell membrane and allowing the contents of the cell to leak out, thus making it unable to replicate again and effectively killing or inactivating the microorganism. It is speculated that the inactivation of a bacteria may also occur via $\mathrm{h}^{+}$before it is trapped either within the semiconductor or at its surface [52]. However, ROS are thought to be the primary "killer", as indicated by the leaking potassium ion from the microorganism membrane or the destruction of its cell structure observed by others [51].

The mechanism described above, while effective, relies on the prevention of rapid recombination of the electron-hole pair. The introduction of a constant stream of oxygen into the system to act as electron scavenger, the addition or in-situ generation of $\mathrm{H}_{2} \mathrm{O}_{2}$ to also act as electron acceptors, and the doping of the photocatalyst with noble metals, are among the most effective techniques being used to impede or delay pair recombination and, at the same time, increase photon absorption in the visible light region. SPR exhibited by noble metal NPs 
also play a very important role in this equation.

\section{SPR Based Visible Light Photocatalytic Disinfection}

\subsection{SPR Phenomenon Overview}

The concept of plasmon resonance in noble metals is well documented [24]-[33]. It is prominent in noble metals NPs as they can utilize visible light energy due to this phenomenon. The SPR of noble metal NPs is the process by which the conducting electrons on the NPs undergo a collective oscillation or excitation stimulated by the oscillating electric field of incoming light rays [53]. As shown in Figure 2, the oscillating charges expand an electrical field close to the surface. When the resonance condition of the noble metal NPs is met by the frequency of the incident energy source, the resultant associated energy absorption leads to the SPR effect [54].

Two conditions must be satisfied for SPR to occur. First, the wavelength of the incident energy must notably surpass the particle diameter, and the shape and/or size of the NP have to be of an optimum magnitude as these variables influence the density of the electromagnetic field at the NP surface. Therefore, under ideal conditions, these two factors bring a shift in the oscillation frequency of the conduction electrons and enhance local electromagnetic fields near the surface of noble metal NPs [55] [56]. For example, metal NPs such as silver and gold possess these attributes and demonstrate distinct plasmon absorption in the visible light region.

The SPR phenomenon provides an alternative approach for triggering light absorption from within the visible light region of the energy spectrum [57]. To quantify SPR, a spherical metal NP is considered. This metal is controlled by dipolar interaction which is described by the polarizability $\alpha$ [53], where:

$$
\alpha=3 \varepsilon_{0} V\left(\varepsilon-\varepsilon_{m}\right) /\left(\varepsilon+2 \varepsilon_{m}\right)
$$

In Equation (5), $V$ is the volume of the nanoparticle, $\varepsilon_{0}$ the vacuum permittivity, $\varepsilon_{m}$ the dielectric constant of the surrounding medium, and $\varepsilon(\omega)=\varepsilon_{r}(\omega)+$ $i \mathcal{E}_{i}(\omega)$, is the frequency-dependent complex dielectric function of the metal with $\varepsilon_{r}(\omega)$ and $\varepsilon_{i}(\omega)$ as the real and imaginary components of $\varepsilon(\omega)$, respectively. When an electromagnetic frequency of $\omega$ at which $\varepsilon_{r}(\omega)=-2 \varepsilon_{m}$ creates a strong resonance, this frequency is known as the SPR frequency. Therefore, the SPR frequency depends on the composition, size and shape of the noble metal NP, and the dielectric property of the adjacent medium due to its polarizing nature. In general, a rise in light intensity increases the possibility of hitting the SPR frequency enabling higher photocatalytic ability [58]. Moreover, smaller nanoparticles have larger specific surface areas but exhibit a weaker SPR effect. Consequently, SPR becomes stronger with increasing nanoparticle size and decreasing specific surface area [59]. Controlling these variables is key in optimizing the NP photosensitive properties [60] [61].

Noble metals have no band gap. Once the conducting electrons in these metals 


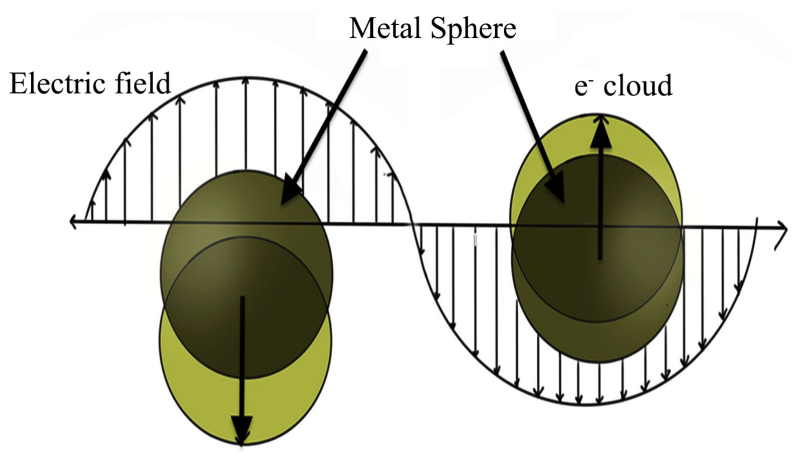

Figure 2. CB electrons of noble metal NP oscillating away from the noble metal nuclei due to resonance with light energy waves [62] [63].

gain energy from light irradiation, the electrons are repositioned to higher energy from lower energy level states. In general, the wavelength (energy) of the incident photons determine the maximum level attained by the energetic electrons in an inter-band transition [63].

However, the energy level reached by the electrons excited by SPR depends on the wavelengths where the SPR absorption is observed. Hence, a wider range of wavelength absorption repositions the electrons to higher energy states, thus negating the need to overcome a band gap. This significant feature distinguishes the light utilization mechanism in metal nanostructures and semiconductors.

The Fermi level of noble metals lies in between the valence band (VB) and conduction band (CB) of a semiconductor photocatalyst [53]. However, noble metal NPs doped or deposited on the semiconductor are not only able to readily form electron-hole pairs, but due to the polarizing nature of the ongoing SPR phenomenon, they also exhibit a significant charge separation within the entire complex. The electrons generated are thus able to travel to the surface and interact with the dissolved oxygen in the bulk solution to form superoxide ions. Additionally, due to the polarized nature of the noble metal NP and semi-conductor interface, the holes may drop into the semiconductors making them into effective electron acceptors [63].

In terms of noble metal NPs that are attached to semiconductors, the SPR of noble-metal NPs is able to instigate a rapid electron transfer from the photoexcited noble metal NP to the semiconductor [64] [65] [66]. The band gap of the semiconductor is essentially reduced by the noble NPs with which it is doped [67]. This occurs as sub-band gap defects, which favor visible light absorption, are generated in the semiconductor complex. Thus, doping alleviates restrictions on the strict wavelength range that a semiconductor can use for photocatalysis.

The presence of noble metal NPs in contact with the semiconductor surface can also accelerate the redox reaction between the semiconductor and $\mathrm{H}_{2} \mathrm{O}, \mathrm{CO}_{2}$ or other organic substances [68] [69]. As shown in Figure 3, this facilitates the transfer of the photogenerated electrons and holes from the photocatalyst enabling them to interact with various species on the surface. 


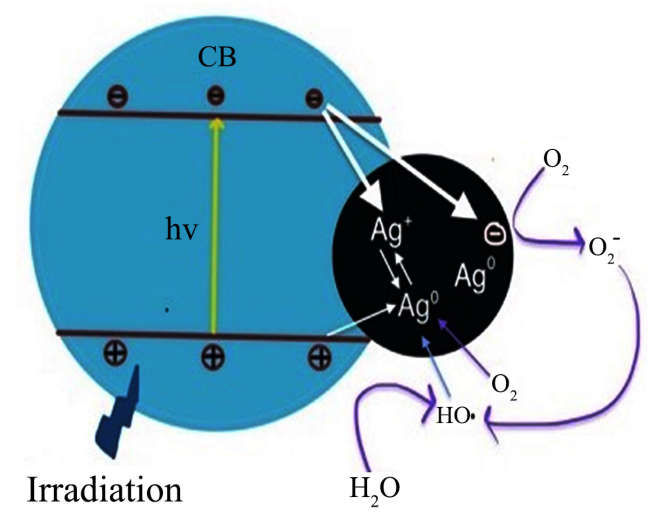

Figure 3. AgNP and semi-conductor interface with AgNP trapping electrons [70].

\subsection{General SPR Mechanisms in Visible Light Photocatalysts}

SPR mechanisms observed in visible light photocatalysts can be separated into five major categories:

(a) the noble metal $\mathrm{NP} /$ noble metal-halogen system, for example, $\mathrm{Ag} / \mathrm{AgX}$ (where $\mathrm{X}$ is a halogen), (b) the noble metal NP/titanium dioxide system, for example $\mathrm{Au} / \mathrm{TiO}_{2}$, (c) the more complex ternary system which comprises more than two components, for example $\mathrm{Ag} / \mathrm{AgBr} / \mathrm{TiO}_{2}$, (d) the noble metal NP/any semiconductor photocatalyst system, and (e) the noble metal salt doped to a traditional photocatalyst system, for example $\mathrm{Ag}_{3} \mathrm{PO}_{4} / \mathrm{TiO}_{2}$ or $\mathrm{AgI} / \mathrm{TiO}_{2}$.

In category (a), Ag NPs absorb photons that potently generate electrons and holes. These photogenerated electrons initially move to the surface of the NPs. The holes however, transfer to the surface of the AgX holding the NP. These holes promote the oxidation of $\mathrm{X}^{-}$ions to $\mathrm{X}^{0}$ atoms, which can then oxidize organic pollutants or microorganisms and reduce back to $\mathrm{X}^{-}$ions in the process. The electrons released are trapped by $\mathrm{O}_{2}$ in solution to form superoxide ions $\mathrm{O}_{2}^{--}$and other ROS [51]. This is the case when the Fermi level of the $\mathrm{AgX}$ is higher than that of Ag NPs [63]. Sarina et al. [63] describe an alternative reaction pathway, of which a good example is observed in the $\mathrm{Ag} / \mathrm{AgBr}$ structure. The symbiotic effect of $\mathrm{Ag}$ and $\mathrm{AgBr}$ in this composite structure occurs from electron transfer between $\mathrm{Ag}$ and $\mathrm{AgBr}$. In this case the electrons generated by the Ag NPs don't just migrate to the surface. As the Fermi energy level of $\mathrm{AgBr}$ is lower than that of $\mathrm{Ag}$, the electrons transfer from $\mathrm{Ag}$ to $\mathrm{AgBr}$ until the two systems attain equilibrium. Under visible light, SPR excited electrons are generated at the surface of Ag NPs. The transfer of SPR electrons from Ag to the CB of $\mathrm{AgBr}$ is then energetically favorable. Alongside the aforementioned plasmonic process, conventional AgBr-based semiconductor photocatalysis also occurs simultaneously because $\mathrm{AgBr}$ can be directly photoexcited under light irradiation to generate electron-hole pairs in $\mathrm{AgBr}$. These photogenerated electrons in the $\mathrm{CB}$, together with the injected SPR electrons from Ag NPs, can initiate the catalytic reaction, as illustrated in Figure 4. 


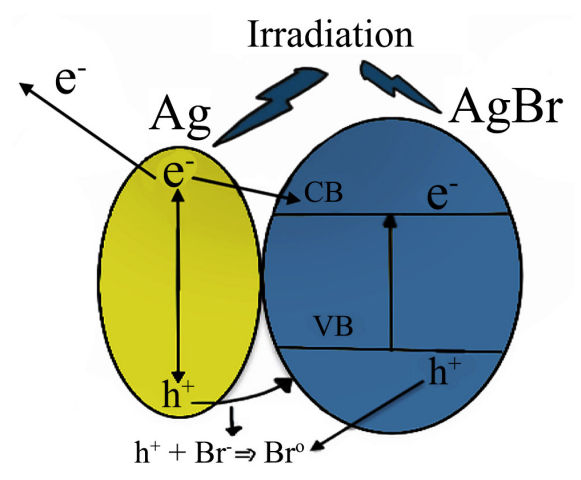

Figure 4. Photocatalytic mechanism of $\mathrm{Ag} / \mathrm{AgBr}$ under visible light irradiation [71].

In category (b), Au NPs doped on semiconductors such as $\mathrm{TiO}_{2}$ act as heterogeneous catalysts for a variety of oxidation reactions. The SPR effect of Au NPs is able to boost the photocatalytic activity of $\mathrm{TiO}_{2}$ [72]. This photolytic reaction is explained by a complex electron transfer mechanism [73] [74]. The Au NP's SPR excitation of conduction electrons induced by incident visible light energy results in the relocation of energized conduction electrons, $\mathrm{e}^{-}$, from the Au NPs to the $\mathrm{TiO}_{2} \mathrm{CB}$, leaving behind positive charges on the Au NPs. The Au NPs can then receive $\mathrm{e}^{-}$from an electron donor. This charge transfer process, where various substrates are oxidized over $\mathrm{Au} N \mathrm{NPs}$, and $\mathrm{O}_{2}$ is reduced on the $\mathrm{CB}$ of $\mathrm{TiO}_{2}$, leads to the generation of ROS [51].

In category (c), exemplified by $\mathrm{Ag} / \mathrm{AgBr} / \mathrm{TiO}_{2}$, the SPR-excited AgNPs serve as electron transfer medium, as shown in Figure 5. Here, the $\mathrm{TiO}_{2}$ also participates in the charge transfer while simultaneously serving as a support for $\mathrm{Ag} / \mathrm{AgBr}$. The linear electron transfer from $\mathrm{AgBr}$ to $\mathrm{Ag}$ to $\mathrm{TiO}_{2}$ occurring in this complex notably improves the interfacial charge transfer and secures stability of the photocatalyst, which reduces the probability of recombination of the electron-hole pair. Oxidative species generated, such as $\mathrm{h}^{+}, \mathrm{OH}^{*}$, and $\mathrm{O}_{2}^{-}$, are heavily involved in the photocatalytic disinfection mechanism of $\mathrm{Ag} / \mathrm{AgBr} / \mathrm{TiO}{ }_{2}$. Another advantage of this new generation photocatalyst is that the surface $\mathrm{Ag}$ species remain $\mathrm{Ag}^{0}$ in the structure. This scavenges the $\mathrm{h}^{+}$and traps the $\mathrm{e}^{-}$in the photocatalytic reaction, inhibiting the decomposition of AgBr. Lastly, this photocatalyst is not only effective under visible light, but it is also effective in the dark, as the antimicrobial properties of silver alone are capable of some degree of disinfection [71] [75].

In category (d), semiconductors like $\mathrm{BiOI}$ and $\mathrm{BiVO}_{4}$ are usually photoactive. They can generate electron-hole pairs via absorbing energy in the visible light region as their bandgaps are smaller, around $2.0 \mathrm{eV}$ [76] [77] [78] [79]. However, their stability is very low, i.e., their electron-hole pair easily recombines [80] [81]. To prevent this from happening, the addition of a noble metal NP, such as $\mathrm{Ag}$, in their structure acts as an electron transfer interface and allows the photocatalyst to promote disinfection in the visible light region, as shown in Figure 3. 


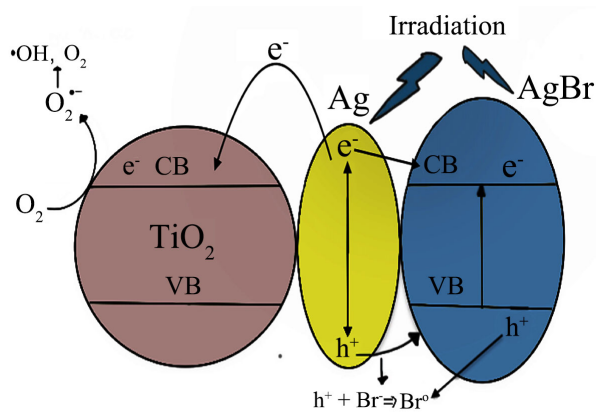

Figure 5. Photocatalytic mechanism of $\mathrm{Ag} / \mathrm{AgBr} / \mathrm{TiO}_{2}$ under visible light irradiation [71].

In category (e), much like in (a), the silver salt can produce electron-hole pairs under visible light irradiation. However, these electrogenerated pairs are weak and recombine easily. Because the $\mathrm{Ag}_{3} \mathrm{PO}_{4}$ nanoparticles can be easily reduced to $\mathrm{Ag}$ nanoparticles and a certain amount of $\mathrm{Ag}$ can form a composite structure of $\mathrm{Ag} / \mathrm{Ag}_{3} \mathrm{PO}_{4} / \mathrm{TiO}_{2}$, the system now functions like a system (c), making the composite structure more stable, unable to recombine electron-hole pairs. Furthermore, the Ti-O-Ag bond in the composite can restrain further decomposition of the $\mathrm{Ag}_{3} \mathrm{PO}_{4}$ and increase the stability of the $\mathrm{Ag}_{3} \mathrm{PO}_{4} / \mathrm{TiO}_{2}$ heterostructure [82] [83].

Regarding the categories previously described, it is important to note that using SPR properties of noble metal NPs in combination with the either polar semiconductors such as $\mathrm{AgBr}$, or a traditional photocatalyst such as $\mathrm{TiO}_{2}$, usually adds to the stability of the photocatalyst and its ability to transfer electrons within the system. Since there is no requirement to overcome a band gap, as there is in the case of semiconductors, the generation of electron-hole pairs in the noble metal NPs happens in the visible light region [63].

In cases such as $\mathrm{AgBr}$ or $\mathrm{Ag}_{3} \mathrm{PO}_{4}$, where the noble metal salt itself is able to generate electron-hole pairs in the visible light region due to reduced bandgap, the addition of another semi-conductor makes the structure even more stable and prone to high efficiency electron transfer, while minimizing the recombination of electron-hole pairs. This system can act symbiotically with the electron-hole pair generated by the noble metal NP in the structure to become more efficient.

In theory, simple noble metal NPs should be able to conduct photocatalysis within the visible light region, however, the addition of supplemental semiconductors make the structure more stable and reusable. Moreover, these noble metal NPs doped onto traditional photocatalysts such as $\mathrm{TiO}_{2}, \mathrm{ZrO}_{2}, \mathrm{Al}_{2} \mathrm{O}_{3}, \mathrm{SiO}_{2}$, or zeolite, will have large specific surface area and porosity, which prevents the aggregation of the NPs and exposes a high number of active catalytic sites to reactant molecules [63]. This is a significant feature that distinguishes the light utilization mechanism of metal nanostructures from semiconductors.

\subsection{Mechanism of Enhanced Photocatalytic Disinfection}

As detailed in Section 2.2, the mechanism of enhanced photocatalytic disinfec- 
tion depends primarily on the oxidative stress caused by ROS which can irreversibly damage biomolecules and inactivate bacteria [84].

\section{Water Disinfection with VLA Photocatalyst}

While Section 3 described the specific structures and generalized mechanism of visible light $(\lambda>380 \mathrm{~nm})$ photocatalytic systems, this section focuses on examining the use of VLA photocatalysts for water disinfection, and, specifically, bacteria annihilation.

\subsection{Bismuth and Noble Metal Based Visible Light Photocatalysts}

Bismuth based photocatalysts exhibit high activity in the visible light region. Bismuth oxyhalides, $\mathrm{BiOX}(\mathrm{X}=\mathrm{Cl}, \mathrm{Br}, \mathrm{I})$, similar to other Bismuth based semiconductors show unique optical properties and promising industrial applications [76] [77] [78] [79]. This section presents the bismuth and noble metal based visible light photocatalysts.

BiOI has noteworthy reactivity in the visible light region, with a bandgap of $1.85 \mathrm{eV}$, and has been used for disinfection [85]. Zhu et al. [85] showed that 7.5 $\log$ Escherichia coli (E. coli) could be inactivated within 30 minutes using BiOI, and $7.7 \log E$. coli could be inactivated within 10 minutes using $\mathrm{Ag} / \mathrm{BiOI}$ at $\lambda>$ $420 \mathrm{~nm}$. The authors concluded that the efficiency of photocatalytic disinfection increased with the increase of Ag content. This increase is due to the capturing of electrons by the deposited $\mathrm{Ag}$ to reduce the recombination of electron-hole pairs [80] [81]. Therefore, while $\mathrm{BiOI}$ and $\mathrm{Ag} / \mathrm{BiOI}$ can both be excited under visible light $(\lambda>420 \mathrm{~nm})$ and possess photocatalytic disinfection activity, doping the bismuth oxyhalide with a noble metal NP enhances the process. This same effect has been observed in several photocatalysts doped with noble metal NP.

Booshehri et al. [52] studied the photocatalytic disinfection ability of $\mathrm{BiVO}_{4}$ and $\mathrm{Ag} / \mathrm{BiVO}_{4}$ by inactivating $E$. coli in aqueous solution under visible light $(\lambda>$ $420 \mathrm{~nm}$ ). Control experiments showed that $E$. coli cannot be inactivated without the photocatalyst either under visible light or in the dark. $\mathrm{BiVO}_{4}$ alone also has a low activity due to the fast recombination of photogenerated electron-ole pairs. However, after the deposition of Ag NPs on the surface of $\mathrm{BiVO}_{4}$, an increase in photocatalytic activity occurred, with all bacterial cells eradicated within 3 hours of irradiation.

Huang et al. [86] reported that $\mathrm{Ag} / \mathrm{Ag}_{3} \mathrm{PO}_{4} / \mathrm{BiPO}_{4}$ demonstrated visible light $(\lambda>420 \mathrm{~nm})$ photocatalytic disinfection activity toward $E$. coli cells. As the band gap of the silver phosphate $\left(\mathrm{Ag}_{3} \mathrm{PO}_{4}\right)$ is quite narrow, it displays a strong photocatalytic activity under the visible light. However, like most silver salts, drawbacks such as high electron-hole recombination rate and weak stability have hindered their practical application in photocatalysis. But enhanced photocatalytic activity and improved stability of $\mathrm{Ag} / \mathrm{Ag}_{3} \mathrm{PO}_{4} / \mathrm{BiPO}_{4}$ contributed to the strong visible light absorption by $\mathrm{Ag} / \mathrm{Ag}_{3} \mathrm{PO}_{4}$ nanostructures. They have a low electron-hole recombination rate, and very efficient photogenerated electron-hole pair separation throughout the $\mathrm{Ag}_{3} \mathrm{PO}_{4} / \mathrm{BiPO}_{4}$ heterostructure. In this case the 
electrogenerated holes were the main reactive species.

Ren et al. [87] reported that compared to $\mathrm{Bi}_{2} \mathrm{WO}_{6}, \mathrm{Ag}-\mathrm{Bi}_{2} \mathrm{WO}_{6}$ photocatalyst exhibited appreciably enhanced photocatalytic activity in inactivating $E$. coli, and Staphylococcus epidermidis ( $S$. epidermidis), a Gram-positive bacterium, under visible light irradiation $(\lambda>420 \mathrm{~nm})$.

Zhang et al. [80] reported that $\mathrm{AgBr}-\mathrm{Ag}-\mathrm{Bi}_{2} \mathrm{WO}_{6}$, a VLA photocatalyst, could completely inactivate $5 \times 10^{7} \mathrm{cfu} / \mathrm{mL}$ E. coli within 15 mins. This was superior to the results reported when using other VLA photocatalysts, such as the $\mathrm{Bi}_{2} \mathrm{WO}_{6}$ superstructure, $\mathrm{Ag}-\mathrm{Bi}_{2} \mathrm{WO}_{6}$ and $\mathrm{AgBr}-\mathrm{Ag}-\mathrm{TiO}_{2}$.

\subsection{Noble Metal Salt and Semi-Conductor Based Visible Light Photocatalysts}

Noble-metal-salt-based VLA photocatalysts are prevalent throughout the literature. Their low bandgap, ease of synthesis and low cost make them favorable for visible light photocatalysis.

Lui et al. [88] reported that $\mathrm{Ag}_{3} \mathrm{PO}_{4} / \mathrm{TiO}_{2}$ composite revealed excellent photocatalytic activity towards disinfecting $E$. coli under visible-light irradiation $(\lambda>$ $400 \mathrm{~nm})$. The $\mathrm{Ag}_{3} \mathrm{PO}_{4}$ nanoparticles enhanced the photocatalytic sterilization activity of $\mathrm{Ag}_{3} \mathrm{PO}_{4} / \mathrm{TiO}_{2}$ heterostructure. $99.86 \%$ E. coli were killed after $50 \mathrm{mi}-$ nutes under visible light irradiation while using this photocatalyst.

Hu et al. [89] evaluated the inactivation of Shigella dysenteriae ( $S$. dysenteriae) in water under visible-light irradiation. Visible light alone without a photocatalyst had no bactericidal effects on $\mathcal{S}$. dysenteriae. However, an approximately 8.5 $\log$ removal of $S$. dysenteriae occurred within 10 and 15 minutes in $\mathrm{Ag}-\mathrm{AgI} / \mathrm{Al}_{2} \mathrm{O}_{3}$ suspension under $\lambda>420 \mathrm{~nm}$ and $\lambda>450 \mathrm{~nm}$ visible-light irradiation, respectively, while the same concentration of $\mathcal{S}$. dysenteriae was completely inactivated after 25 minutes in $\mathrm{AgI} / \mathrm{Al}_{2} \mathrm{O}_{3}$ suspension under $\lambda>420 \mathrm{~nm}$ irradiation.

Lan et al. [90] reported that the photocatalytic inactivation of bacteria in water with $\mathrm{AgBr} / \mathrm{TiO}_{2}$ under visible light $(\lambda>420 \mathrm{~nm})$ irradiation was highly successful for the killing of $E$. Coli, and Staphylococcus aureus ( $S$. aureus). The same authors also reported that $S$. aureus and $E$. coli, were almost completely destroyed by $\mathrm{AgI} / \mathrm{TiO}_{2}$ in suspension under visible light irradiation. $7.8 \mathrm{log}$ elimination of $E$. coli and $7.0 \mathrm{log}$ removal of $S$. aureus occurred in 60 and $100 \mathrm{mi}-$ nutes, respectively [90].

Similar results were observed in separate photocatalytic experiments using $\mathrm{Ag} / \mathrm{AgBr} / \mathrm{TiO}_{2}$ where $6 \mathrm{log}$ removal of $E$. coli was achieved in 60 minutes under visible light irradiation [71]. Also, others [89] report that 1.6 log removal of Gram-negative $S$. dysenteriae was attained after 40 minutes in a dispersion of $\mathrm{Ag} / \mathrm{AgI} / \mathrm{Al}_{2} \mathrm{O}_{3}$ in the dark, and a $8.5 \log$ destruction of $S$. dysenteriae resulted from 10 minutes in a $\mathrm{Ag} / \mathrm{AgI} / \mathrm{Al}_{2} \mathrm{O}_{3}$ suspension under visible light irradiation.

\subsection{Miscellaneous Noble Metal Based Visible Light Photocatalysts}

The practice of adding graphene to make a visible light photocatalyst stable is well known [91]. This section gives examples of such visible light photocatalysts 
and other unconventional newer photocatalysts.

Yang et al. [91] confirmed that the hybridization of $\mathrm{Ag}_{3} \mathrm{PO}_{4}$ with graphene oxide (GO) sheets not only resulted in the enhancement of the visible light absorption, but also lead to an improved visible light photocatalytic performance [92] [93] [94]. The addition of GO sheets eased charge transfer and quelled the recombination of photogenerated electrons and holes. It was also reported that, for $\lambda>420 \mathrm{~nm}$, when a composite of $\mathrm{TiO}_{2} / \mathrm{Ag}_{3} \mathrm{PO}_{4} / \mathrm{GR}$ was synthesized (GR indicating graphene from the graphene oxide compound), it efficiently annihilated various bacteria. Within the first 2 hours, the bacterial population was observed to decrease drastically from above $6-6.5 \log \mathrm{CFU} / \mathrm{mL}$ of the control to $2.1-2.4 \log \mathrm{CFU} / \mathrm{mL}$ for $S$. aureus and Bacillus subtilis (B. subtilis), and around $1.0 \log \mathrm{CFU} / \mathrm{mL}$ for Pseudomonas aeruginosa ( $P$. aeruginosa) and Bacillus pumilus (B. pumilus). When the time was extended to 4 hours, bacterial counts continued to decrease and the number of cells of all bacteria stabilized around 1 $\log \mathrm{CFU} / \mathrm{mL}$. After 8 hours, the bacterial population was completely inactivated.

Erkan et al. [95] doped $\mathrm{SnO}_{2}$ and $\mathrm{TiO}_{2}$ with $\mathrm{Pd}$ for microbial inactivation of $E$. coli, S. aureus and Saccharomyces cerevisiae (S. cerevisiae). The addition of Pd led to an enhancement in the photocatalytic efficiency for the degradation of microorganisms when $1 \%$ Pd was used.

Table 1 shows a comparison of the discussed photocatalysts, experimental setting and other pertinent information. The kinetic constant, $\mathrm{K}$, has also been calculated for uniform comparison of photocatalyst performance assuming first order kinetics for all disinfection reactions. Most reactions occurred in a batch-like setting with slight modifications. As there is not a unified convention for photocatalyst nomenclature, their designated names are as provided in the literature and based on their synthesis procedure.

\section{Synthesis of Selected Noble-Metal VLA Photocatalysts Used in Water Disinfection}

Different laboratory methods used for synthetizing noble-metal-based photocatalyst have been developed by researchers in the field. Some of these methods for synthetizing a few selected photocatalysts are summarized below.

\section{1. $\mathrm{Ag} / \mathrm{AgBr} / \mathrm{TiO}_{2}[71]$}

$\mathrm{Ag} / \mathrm{AgBr} / \mathrm{TiO}_{2}$ is synthesized in a two-step process requiring the fabrication of $\mathrm{AgBr} / \mathrm{TiO}_{2}$ as an intermediary product using either the sol-gel or the solvothermal method.

\subsection{1. $\mathrm{AgBr} / \mathrm{TiO}_{2}$ via Sol-Gel ROUTE}

Ethanol (99.5\% - 99.8\%) is used to prepare solutions A and B. Solution A $(45 \mathrm{~mL}$ total) contains 0.16 gram (g) of silver nitrate $\left(\mathrm{AgNO}_{3}\right)(98 \%)$ and 2 milliliter (mL) of ammonia ( $25 \mathrm{wt} \%)$. Solution B ( $45 \mathrm{~mL}$ total) consists of $0.91 \mathrm{~g}$ cetyltrimethylammonium bromide (CTAB, $98 \%$ ) followed by $2.98 \mathrm{~mL}$ of titanium isopropoxide (TTIP, 98\%), which is added at last. The mixture of these two solu- 
tions is continuously stirred for 3 hours at room temperature. The resulting light-yellow gel is dried at 70 degree Celsius $\left({ }^{\circ} \mathrm{C}\right)$ overnight and calcined at $450{ }^{\circ} \mathrm{C}$ for 2 hours.

Table 1. Comparison of noble metal based visible light disinfecting photocatalysts.

\begin{tabular}{|c|c|c|c|c|c|}
\hline Photocatalyst & $\begin{array}{l}\text { Wavelength } \\
(\lambda)>\end{array}$ & Bacteria & $\begin{array}{l}\text { Kinetic constant } \\
\text { K. } 1 / \text { min }\end{array}$ & Additional experimental information & Reference \\
\hline \multirow[t]{4}{*}{$\mathrm{Ag} / \mathrm{BiOI}$} & $420 \mathrm{~nm}$ & E. coli & 1.2434 & $400 \mathrm{~W}$ commercial iodine lamp & {$[85]$} \\
\hline & & & & $\lambda>420 \mathrm{~nm}$, made by cut-off filter & \\
\hline & & & & $0.5 \mathrm{~g} / \mathrm{l}$ of photocatalyst used & \\
\hline & & & & $\begin{array}{l}\text { Photocatalyst synthesized by solvothermal and } \\
\text { deposition }\end{array}$ & \\
\hline \multirow[t]{4}{*}{$\mathrm{Ag} / \mathrm{BiVO}_{4}$} & $420 \mathrm{~nm}$ & E. coli & $8.95 \mathrm{E}-02$ & $\begin{array}{l}300 \mathrm{~W} \text { xenon lamp. } \lambda>420 \mathrm{~nm} \text { made by cut-off } \\
\text { filter }\end{array}$ & {$[52]$} \\
\hline & & & & $19.7 \% \mathrm{Ag}$ in photocatalyst & \\
\hline & & & & $\begin{array}{l}30 \mathrm{ml} \text { bacterial solution added to } 2 \mathrm{mg} / \mathrm{ml} \text { of solid } \\
\text { photocatalyst }\end{array}$ & \\
\hline & & & & $\begin{array}{l}\text { Photocatalyst synthesized by precipitation and } \\
\text { deposition }\end{array}$ & \\
\hline \multirow[t]{3}{*}{$\mathrm{AgBr}-\mathrm{Ag}-\mathrm{Bi}_{2} \mathrm{WO}_{6}$} & $400 \mathrm{~nm}$ & E. coli & $9.98 \mathrm{E}-01$ & $\begin{array}{l}300 \mathrm{~W} \text { xenon lamp, } \lambda>400 \mathrm{~nm} \text { made by cut-off } \\
\text { filter }\end{array}$ & {$[80]$} \\
\hline & & & & $100 \mathrm{mg} / \mathrm{l}$ of photocatalyst used & \\
\hline & & & & $\begin{array}{l}\text { Photocatalyst synthesized by hydrothermal and } \\
\text { precipitation }\end{array}$ & \\
\hline \multirow[t]{3}{*}{$\mathrm{AgBr}-\mathrm{Ag}-\mathrm{TiO}_{2}$} & $400 \mathrm{~nm}$ & E. coli & 0.07675 & $\begin{array}{l}300 \mathrm{~W} \text { xenon lamp. } \lambda>400 \mathrm{~nm} \text { made by cut-off } \\
\text { filter }\end{array}$ & {$[80]$} \\
\hline & & & & $100 \mathrm{mg} / \mathrm{l}$ of photocatalyst used & \\
\hline & & & & $\begin{array}{l}\text { Photocatalyst synthesized by hydrothermal, } \\
\text { deposition and precipitation }\end{array}$ & \\
\hline \multirow[t]{3}{*}{$\mathrm{Ag}-\mathrm{Bi}_{2} \mathrm{WO}_{6}$} & $400 \mathrm{~nm}$ & E. coli $\mathrm{K}-12$ & 0.03071 & $\begin{array}{l}300 \mathrm{~W} \text { xenon lamp, } \lambda>400 \mathrm{~nm} \text { made by cut-off } \\
\text { filter }\end{array}$ & {$[80]$} \\
\hline & & & & $100 \mathrm{mg} / \mathrm{l}$ of photocatalyst used & \\
\hline & & & & $\begin{array}{l}\text { Photocatalyst synthesized by deposition and } \\
\text { precipitation }\end{array}$ & \\
\hline \multirow[t]{4}{*}{$\mathrm{Ag}-\mathrm{AgI} / \mathrm{Al}_{2} \mathrm{O}_{3}$} & $450 \mathrm{~nm}$ & E. coli & $3.11 \mathrm{E}-01$ & $\begin{array}{l}\text { Photocatalyst synthesized by } \\
\text { deposition-precipitation and photoreduction }\end{array}$ & [89] \\
\hline & $450 \mathrm{~nm}$ & S. dysenteriae & 1.304 & $200 \mathrm{mg} / \mathrm{l}$ of photocatalyst used & \\
\hline & $420 \mathrm{~nm}$ & S. dysenteriae & 1.956 & Best activity seen at $\mathrm{pH} 8.5$ & \\
\hline & & & & $\lambda>420$ and $450 \mathrm{~nm}$ made by cut-off filters & \\
\hline \multirow[t]{2}{*}{$\mathrm{Ag}-\mathrm{AgBr} / \mathrm{TiO}_{2}$} & $400 \mathrm{~nm}$ & E. coli & $2.30 \mathrm{E}-01$ & $\begin{array}{l}\text { Photocatalyst synthesized by sol-gel, solvothermal } \\
\text { and photoreduction }\end{array}$ & [71] \\
\hline & & & & $0.5 \mathrm{~g} / \mathrm{L}$ of photocatalyst used & \\
\hline
\end{tabular}




\section{Continued}

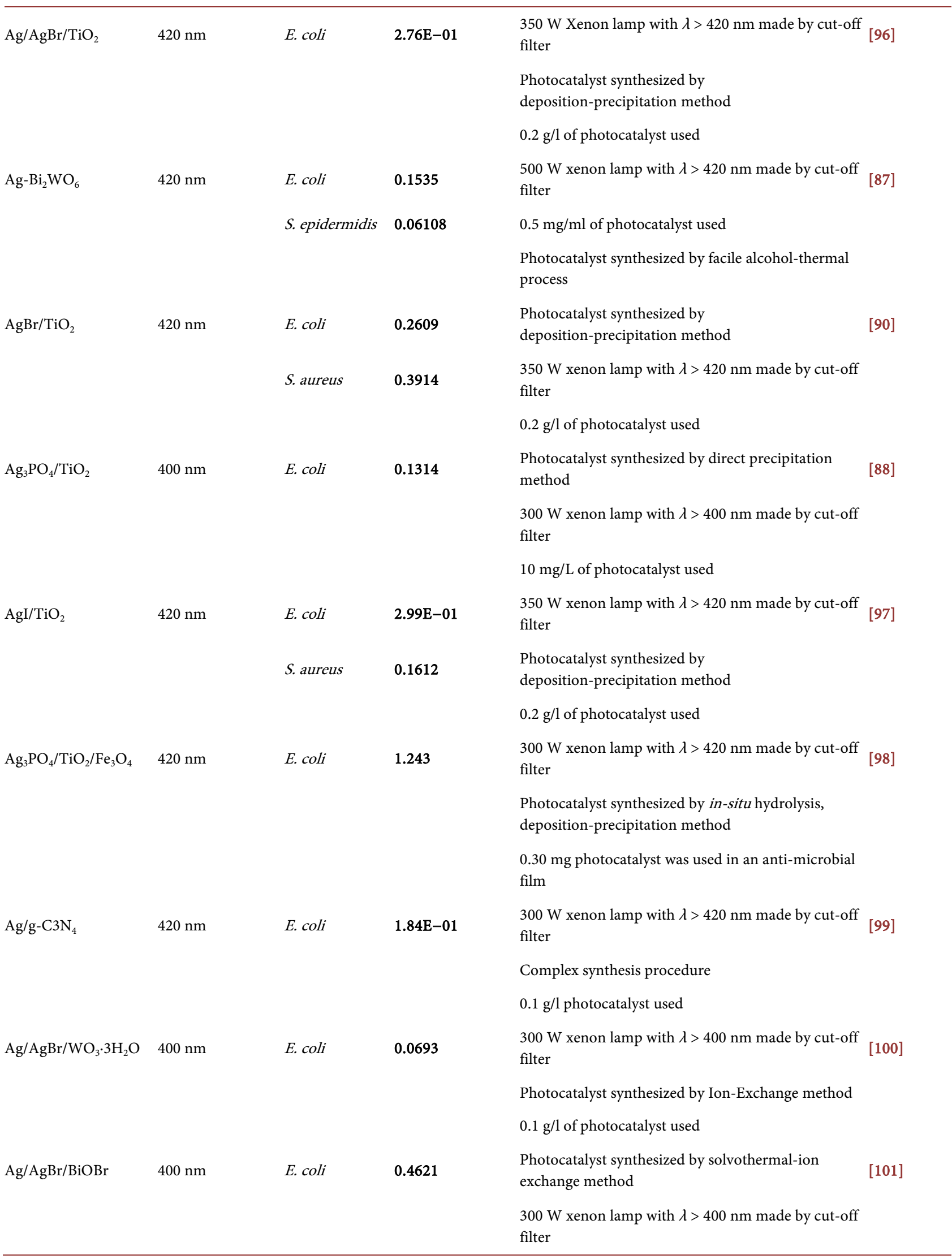




\subsection{2. $\mathrm{AgBr} / \mathrm{TiO}_{2}$ via Solvothermal Route}

A mixture of solutions containing $\mathrm{AgNO}_{3}, \mathrm{CTAB}$ and TTIP is prepared similarly to the sol-gel route. This mixture is then transferred into a $100 \mathrm{~mL}$ Teflon-lined stainless-steel autoclave. The autoclave is solvothermally treated at $150^{\circ} \mathrm{C}$ for 4 hours. The resulting product is thoroughly washed with deionized (DI) water, centrifuged and dried at $70^{\circ} \mathrm{C}$ overnight. It is lastly calcined at $450^{\circ} \mathrm{C}$ for 2 hours.

The obtained yellow powder of $\mathrm{AgBr} / \mathrm{TiO}_{2}$ is then dispersed into deionized (DI) water under dynamic stirring and white Light Emitting Diode (LED) irradiation for 2 hours. The product is then collected and dried at $70^{\circ} \mathrm{C}$. The gray $\mathrm{Ag} / \mathrm{AgBr} / \mathrm{TiO}_{2}$ photocatalyst is finally obtained.

\section{2. $\mathrm{AgI} / \mathrm{TiO}_{2}[75]$}

$\mathrm{AgI} / \mathrm{TiO}_{2}$ is synthesized by a decomposition-precipitation method. $1.0 \mathrm{~g}$ of $\mathrm{P} 25$ $\mathrm{TiO}_{2}$ is added into $100 \mathrm{~mL}$ of distilled water. This suspension is sonicated for 30 minutes. $0.205 \mathrm{~g}$ of potassium iodide (KI) is added to the sonicated suspension, and the mixture is stirred magnetically for 30 minutes. Next, $0.21 \mathrm{~g}$ of $\mathrm{AgNO}_{3}$ in $2.3 \mathrm{~mL}$ of ammonium hydroxide $\left(\mathrm{NH}_{4} \mathrm{OH}\right)(25$ percent weight (wt\%) ammonia $\left(\mathrm{NH}_{3}\right)$ ) is swiftly added to the mixture. The resulting suspension is stirred at room temperature for 12 hours. The product is firstly filtered, then washed with DI water, finally dried at $70^{\circ} \mathrm{C}$. The yellow $\mathrm{AgI} / \mathrm{TiO}_{2}$ is eventually obtained.

\section{3. $\mathrm{Ag} / \mathrm{AgI} / \mathrm{Al}_{2} \mathrm{O}_{3}[102][103]$}

Synthesis of $\mathrm{Ag} / \mathrm{AgI} / \mathrm{Al}_{2} \mathrm{O}_{3}$ requires preparation of $\mathrm{Al}_{2} \mathrm{O}_{3}$ followed by deposition of AgI. Finally, $\mathrm{Ag} / \mathrm{AgI} / \mathrm{Al}_{2} \mathrm{O}_{3}$ is prepared using a photocatalytic reduction method.

\subsection{1. $\mathrm{Al}_{2} \mathrm{O}_{3}$}

$4.2 \mathrm{~g}$ of aluminium i-propoxide $\left(\mathrm{C}_{9} \mathrm{H}_{21} \mathrm{AlO}_{3}\right)$ and $3.6 \mathrm{~g}$ of glucose $\left(\mathrm{C}_{6} \mathrm{H}_{12} \mathrm{O}_{6}\right)$ is dissolved in $54 \mathrm{ml}$ of distilled water. The resultant solution is magnetically stirred at room temperature for 30 minutes. A diluted aqueous nitric acid $\left(\mathrm{HNO}_{3}\right)$ (10 wt\%) solution is then added dropwise to adjust the $\mathrm{pH}$ value to about 5.0. After 5 hours, the mixture is heated at $100^{\circ} \mathrm{C}$. The resulting solid is then calcined at $600^{\circ} \mathrm{C}$ for 6 hours. $\mathrm{Al}_{2} \mathrm{O}_{3}$ is produced.

\subsection{2. $\mathrm{AgI} / \mathrm{Al}_{2} \mathrm{O}_{3}$}

$\mathrm{AgI}$ is then deposited onto $\mathrm{Al}_{2} \mathrm{O}_{3}$ using a deposition-precipitation method similar to the aforementioned $\mathrm{AgI} / \mathrm{TiO}_{2}$ production, yielding a dark yellow $\mathrm{AgI} / \mathrm{Al}_{2} \mathrm{O}_{3}$.

\subsection{3. $\mathrm{Ag} / \mathrm{AgI} / \mathrm{Al}_{2} \mathrm{O}_{3}$}

A suspension of $0.5 \mathrm{~g} \mathrm{AgI} / \mathrm{Al}_{2} \mathrm{O}_{3}$ in $50 \mathrm{~mL}$ of DI water is sonicated for $30 \mathrm{mi}$ nutes. The $\mathrm{pH}$ of the suspension is adjusted to 5.97 with a dilute $\mathrm{HNO}_{3}$ solution. $0.05 \mathrm{~g}$ octadecylamine acetate $\left[\mathrm{CH}_{3}\left(\mathrm{CH}_{2}\right) 17 \mathrm{NH}_{2} \cdot \mathrm{CH}_{3} \mathrm{COOH}\right]$ is then added to the suspension and magnetically stirred at $70^{\circ} \mathrm{C}$ until the surfactant is dissolved. $7.9 \mathrm{mg}$ of $\mathrm{AgNO}_{3}$ in $0.08 \mathrm{~mL} \mathrm{NH}_{4} \mathrm{OH}\left(25 \mathrm{wt} \% \mathrm{NH}_{3}\right)$ are added to the mixture and stirred in the dark for 30 minutes. The product is then filtered, dried at 
$100^{\circ} \mathrm{C}$, and calcined in air at $500^{\circ} \mathrm{C}$ for 3 hours. The resulting powder is mixed with DI water and irradiated with visible light $(\lambda>390 \mathrm{~nm})$ for 4 hours. Finally, the product is filtered, washed with DI water, and dried at room temperature. The prepared $\mathrm{Ag} / \mathrm{AgI} / \mathrm{Al}_{2} \mathrm{O}_{3}$ is dark gray.

\section{4. $\mathrm{TiO}_{2} / \mathrm{Ag} / \mathrm{SnO}_{2}[104]$}

First, $1.0 \mathrm{~g}$ of $\mathrm{P} 25 \mathrm{TiO}_{2}$ is sonicated in $100 \mathrm{~mL}$ DI water. Next, an aqueous solution containing $0.5 \mathrm{~g}$ of Tin dichloride $\left(\mathrm{SnCl}_{2}\right)$ and $3.0 \mathrm{~mL}$ of hydrochloric acid $(\mathrm{HCl})$ is added into the aforementioned solution. This solution is magnetically stirred at room temperature for 12 hours. The precipitate is collected by centrifugation and washed with water. It is then re-dispersed into $70 \mathrm{~mL}$ DI water. Next, $0.5 \mathrm{~mL}$ of $50-\mathrm{mmol} \mathrm{AgNO}_{3}$ solution is added to the solution. After $30 \mathrm{mi}$ nutes, $2 \mathrm{~mL}$ of 0.15 -mol sodium formate (HCOONa) solution is added to form a mixture. This mixture is magnetically stirred for another 4 hours, and then the product is collected after centrifugation, washed with water and dried in a vacuum oven at $75^{\circ} \mathrm{C}$.

\section{5. $\mathrm{Ag} / \mathrm{BiVO}_{4}[52]$}

$\mathrm{BiVO}_{4}$ was synthesized by a homogeneous precipitation method. First, $6 \mathrm{mmol}$ of $\mathrm{Bi}\left(\mathrm{NO}_{3}\right)_{3} \cdot 5 \mathrm{H}_{2} \mathrm{O}$ was dissolved in $32 \mathrm{~mL}$ of $1 \mathrm{M} \mathrm{HNO}_{3}$ aqueous solution. This was stirred until a clear solution formed. Next, an equal number of moles of $\mathrm{NH}_{4} \mathrm{VO}_{3}$ was added to this solution. $3.0 \mathrm{~g}$ of urea was added to the mixture, after its color had changed to yellowish orange. This mixture was heated to $80^{\circ} \mathrm{C}$. This mixture was then kept at this temperature for 24 hours. The resultant precipitate was washed thoroughly with deionized water until the $\mathrm{pH}$ of the supernatant solution reached about 7.0. This washed sample was then dried overnight in an oven at $60^{\circ} \mathrm{C}$.

Ag NPs were deposited onto the $\mathrm{BiVO}_{4}$ by a photodeposition method. The as-prepared $\mathrm{BiVO}_{4}(100 \mathrm{mg})$ was dispersed in $50 \mathrm{~mL}$ of deionized water. Consequently, relevant amount of $\mathrm{AgNO}_{3}$ was added. The mixture was irradiated by a Xe lamp ( $300 \mathrm{~W}, \lambda>420 \mathrm{~nm}$ by equipping a long-pass cut-off filter) for 1 hour. The resultant sample was thoroughly washed with deionized water and dried in a freeze drier overnight.

\section{6. $\mathrm{Ag} / \mathrm{BiOI}[85]$}

BiOI was synthesized by the Solvothermal process. First, 0.05 moles of $\mathrm{Bi}\left(\mathrm{NO}_{3}\right)_{3} \cdot 5 \mathrm{H}_{2} \mathrm{O}$ was added into a 300 -ml-ethylene glycol solution containing dissolved $\mathrm{KI}$ with equivalent molar ratio. This mixture was stirred at room temperature for 1 hour until it became homogeneous. It was then transferred into a $100 \mathrm{ml}$ Teflon-lined stainless-steel autoclave. This mixture was kept at $160^{\circ} \mathrm{C}$ for 12 hours inside the autoclave. After the heating phase, the autoclave was taken out of the oven and left to cool down at room temperature. Lastly, the precipitate was centrifuged, filtered through a $0.22 \mu \mathrm{m}$ Millipore membrane, and then washed 
with deionized water and ethanol three times until the impurities were removed. The resulting product was dried in a vacuum oven at $70^{\circ} \mathrm{C}$ for 6 hours.

The $\mathrm{Ag} / \mathrm{BiOI}$ composite was prepared by photodepositing Ag onto the BiOI particles. The preparation is as follows: $1 \mathrm{~g}$ of BiOI powder and a reasonable amount of $\mathrm{AgNO}_{3}$ was added into $40 \mathrm{ml}$ of aqueous solution containing 10 $\mathrm{mmol} / \mathrm{L} \mathrm{HCOOH}$. The $\mathrm{HCOOH}$ acted as a hole scavenger. The mixture was sonicated for 30 minutes and then stirred magnetically for 30 minutes to form a fine BiOI suspension. Next, to conduct photoreduction reaction the suspension was illuminated with a $500 \mathrm{~W}$ high pressure mercury lamp for 2 hours. Here, $\mathrm{Ag}^{+}$was reduced to $\mathrm{Ag}$ and evenly deposited onto the surface of BiOI particles.

\section{7. $\mathrm{Ag} / \mathrm{Ag}_{3} \mathrm{PO}_{4} / \mathrm{BiPO}_{4}[86]$}

The impregnation method was used to synthesize $\mathrm{Ag} / \mathrm{Ag}_{3} \mathrm{PO}_{4} / \mathrm{BiPO}_{4}$. First, 1.25 $\mathrm{mmol}$ of $\mathrm{Bi}\left(\mathrm{NO}_{3}\right)_{3} \cdot 5 \mathrm{H}_{2} \mathrm{O}$ and $2.5 \mathrm{mmol}$ of $\mathrm{Na}_{3} \mathrm{PO}_{4}$ were added in a beaker. Then, $46 \mathrm{~mL}$ deionized water and $1 \mathrm{~mL}$ of a $4 \mathrm{M} \mathrm{HNO}_{3}$ were also added to the beaker. The mixture was magnetically stirred to form a homogeneous solution at room temperature. After 1 minute, a white precipitate formed and this was transferred to a Teflon-lined stainless-steel autoclave. This was heated at $180^{\circ} \mathrm{C}$ for 24 hours. After the autoclave cooled off, a white $\mathrm{BiPO}_{4}$ powder was obtained through centrifugation. This powder was then washed three times with deionized water and ethanol, and then dried in a desiccator at $55^{\circ} \mathrm{C}$ for 12 hours. Separately, a reasonable amount of $\mathrm{AgNO}_{3}$ was dissolved in $2 \mathrm{~mL}$ of distilled water, and $0.3 \mathrm{~g}$ of the previously obtained $\mathrm{BiPO}_{4}$ powder was dispersed in the $\mathrm{AgNO}_{3}$ solution while it was magnetically stirred to yield a uniform precursor. This precursor was then kept at $80^{\circ} \mathrm{C}$ for 10 hours to get all the water to evaporate. Finally, the obtained powder was calcined at $500^{\circ} \mathrm{C}$ for 6 hours to produce $\mathrm{Ag} / \mathrm{Ag}_{3} \mathrm{PO}_{4} / \mathrm{BiPO}_{4}$ heterostructures.

\section{Conclusions}

Although waterborne diseases have plagued humans throughout history, it is a concern that even today many developing nations lack proper water disinfecting systems. As the human population becomes more economically and geographically sizeable and diverse, the need for sustainable, inexpensive, scalable, and decentralized water treatment technologies to supplement or replace conventional treatment methods is greater than ever, especially for satisfying the need of small, rural communities for safe drinking water.

The challenges can be partially met with the use of semiconductor photocatalysis, particularly if the process is driven by visible light energy. VLA photocatalysis, as discussed in this paper, can be effectively applied in disinfection of drinking water. In comparison to traditional, energy-intensive, physical and chemical disinfection methods, VLA photocatalysis is capable of providing high disinfection efficiency with the use of cheaper energy, no harmful by-products, and no addition of chemicals. Doped with noble metals, some photocatalysts can 
be improved to react under visible light, producing in-situ ROS to disinfect water. Either by reducing the bandgap of the semi-conductors to operate within visible light region, or by delaying the recombination of electron-hole pair via the SPR effect, certain new generation photocatalysts are very effective in disinfecting water.

As presented in Table 1, photocatalysts $\mathrm{Ag} / \mathrm{BiOI}, \mathrm{Ag}-\mathrm{AgI} / \mathrm{Al}_{2} \mathrm{O}_{3}$ and $\mathrm{Ag}_{3} \mathrm{PO}_{4} / \mathrm{TiO}_{2} / \mathrm{Fe}_{3} \mathrm{O}_{4}$ appear to be the most efficient for pathogen inactivation in a photocatalytic setting, according to the predicted kinetic constant $\mathrm{K}$.

Although considerable progress has been made in all aspects of visible-light photocatalysis, studies in this field are still at a nascent stage, and further research is necessary to increase the efficiency, stability, economic viability, and adoption of this technology for water disinfection.

Some of the issues/challenges that future research in this area will have to address include the economic analysis of the ability of photocatalytic water inactivation technology to compete with conventional water treatment, the feasibility to mass produce VLA photocatalysts, the viability and technology for recovering photocatalysts after usage, residual effect of photocatalytic disinfection in larger water treatment plants, the potential sources of light for VLA disinfection including natural sunlight or LED lamps, and the effect of generating in-situ ROS using electricity to supplement VLA photocatalysis.

\section{Acknowledgements}

Writing, A.U; Supervision, G.R.

\section{Conflicts of Interest}

The authors declare no conflicts of interest regarding the publication of this paper.

\section{References}

[1] Magnusson, R. (2001) Water Technology in the Middle Ages. Johns Hopkins University Press, Baltimore.

[2] Johnson, S. (2006) The Ghost Map. Riverhead Books, New York.

[3] Sedgwick, W. (1943) Principles of Sanitary Science and the Public Health. 3rd Edition, Macmillan Company, London.

[4] World Health Organization (2018) Drinking-Water. https://www.who.int/news-room/fact-sheets/detail/drinking-water

[5] Nieuwenhuijsen, M., Toledano, M., Eaton, N., Fawell, J. and Elliott, P. (2000) Chlorination Disinfection Byproducts in Water and Their Association with Adverse Reproductive Outcomes: A Review. Occupational and Environmental Medicine, 57, 73-85. https://doi.org/10.1136/oem.57.2.73

[6] Maeda, K., Teramura, K., Lu, D.L., Takata, T., Saito, N., Inoue, Y. and Domen, K. (2006) Photocatalyst Releasing Hydrogen from Water. Nature, 440, 295. https://doi.org/10.1038/440295a

[7] Warren, S. and Thimsen, E. (2012) Plasmonic Solar Water Splitting. Energy, Envi- 
ronmental Science, 5, 5133-5146. https://doi.org/10.1039/C1EE02875H

[8] Liu, Q., Zhou, Y., Kou, J.H., Chen, X.Y., Tian, Z.P., Gao, J., Yan, S.C. and Zou, Z.G. (2010) ChemInform Abstract: High-Yield Synthesis of Ultralong and Ultrathin $\mathrm{Zn}_{2} \mathrm{GeO}_{4}$ Nanoribbons toward Improved Photocatalytic Reduction of $\mathrm{CO}_{2}$ into Renewable Hydrocarbon Fuel. Journal of the American Chemical Society, 132, 14385-14387. https://doi.org/10.1002/chin.201104009

[9] Fujishima, A. and Honda, K. (1972) Electrochemical Photolysis of Water at a Semiconductor Electrode. Nature, 238, 37-38. https://doi.org/10.1038/238037a0

[10] Bard, A.J. (1979) Photoelectrochemistry and Heterogeneous Photocatalysis at Semiconductors. Journal of Photochemistry, 10, 59-75. https://doi.org/10.1016/0047-2670(79)80037-4

[11] Bard, A.J. (1980) Photoelectrochemistry. Science, 207, 139-144. https://doi.org/10.1126/science.207.4427.139

[12] Bard, A.J. (1982) Design of Semiconductor Photo-Electrochemical Systems for Solar-Energy Conversion. The Journal of Physical Chemistry, 86, 172-177. https://doi.org/10.1021/j100391a008

[13] Kalyanasundaram, K., Gratzel, M. and Pelizzetti, E. (1986) Interfacial Electron-Transfer in Colloidal Metal and Semiconductor Dispersions and Photodecomposition of Water. Coordination Chemistry Reviews, 69, 57-125. https://doi.org/10.1016/0010-8545(86)85009-3

[14] Bavykin, V., Dmitry, M., Friedrich, J. and Walsh, F. (2006) Protonated Titanates and $\mathrm{TiO}_{2}$ Nanostructured Materials: Synthesis, Properties, and Applications. Advanced Materials, 18, 2807-2824. https://doi.org/10.1002/adma.200502696

[15] Yoon, P., Tehshik, A., Ischay, M. and Du, J. (2010) Visible Light Photocatalysis as a Greener Approach to Photochemical Synthesis. Nature Chemistry, 2, 527-532. https://doi.org/10.1038/nchem.687

[16] Wang, P., Huang, B.B., Qin, X.Y., Zhang, X.Y., Dai, Y., Wei, J.Y. and Whangbo, M.-H. (2008) Ag@AgCl: A Highly Efficient and Stable Photocatalyst Active under Visible Light. Angewandte Chemie, 47, 7931-7933. https://doi.org/10.1002/anie.200802483

[17] Watanabe, K., Menzel, D., Nilius, N. and Freund, H.-J. (2006) Photochemistry on Metal Nanoparticles. Chemical Reviews, 106, 4301-4320. https://doi.org/10.1021/cr050167g

[18] Camden, J.P., Dieringer, J.A., Zhao, J. and Van Duyne, R.P. (2008) Controlled Plasmonic Nanostructures for Surface-Enhanced Spectroscopy and Sensing. Accounts of Chemical Research, 41, 1653-1661. https://doi.org/10.1021/ar800041s

[19] Stewart, M.E., Anderton, C.R., Thompson, L.B., Maria, J., Gray, S., Rogers, J.A. and Nuzzo, R.G. (2008) Nanostructured Plasmonic Sensors. Chemical Reviews, 108, 494-521. https://doi.org/10.1021/cr068126n

[20] Kneipp, K., Kneipp, H. and Kneipp, J. (2006) Surface-Enhanced Raman Scattering in Local Optical Fields of Silver and Gold Fields of Silver and Gold Nanoaggregates-From Single-Molecule Raman Spectroscopy to Ultrasensitive Probing in Live Cells. Accounts of Chemical Research, 39, 443-450. https://doi.org/10.1021/ar050107x

[21] Ghosh, S. and Pal, T. (2007) Interparticle Coupling Effect on the Surface Plasmon Resonance of Gold Nanoparticles: From Theory to Applications. Chemical Reviews, 107, 4797-4862. https://doi.org/10.1021/cr0680282

[22] Wang, H., Brandl, D.W., Nordlander, P. and Halas, N. (2007) Plasmonic Nano- 
structures: Artificial Molecules. Accounts of Chemical Research, 40, 53-62. https://doi.org/10.1021/ar0401045

[23] Kühn, S., Håkanson, U., Rogobete, L. and Sandoghdar, V. (2006) Enhancement of Single-Molecule Fluorescence Using a Gold Nanoparticle as an Optical Nanoantenna. Physical Review Letters, 97, Article ID: 017402. https://doi.org/10.1103/PhysRevLett.97.017402

[24] Murray, W.A. and Barnes, L.W. (2007) Plasmonic Materials. Advanced Materials, 19, 3771-3782. https://doi.org/10.1002/adma.200700678

[25] Chen, H.J., Sun, Z.H., Ni, W.H., Woo, K.C., Lin, H.-Q., Sun, L.D., Yan, C.H. and Wang, J.F. (2009) Plasmon Coupling in Clusters Composed of Two-Dimensionally Ordered Gold Nanocubes. Small, 5, 2111-2119. https://doi.org/10.1002/smll.200900256

[26] Schmucker, A.L., Harris, N., Banholzer, M.J., Blaber, M., Osberg, K.D., Schatz, G.C. and Mirkin, C.A. (2010) Correlating Nanorod Structure with Experimentally Measured and Theoretically Predicted Surface Plasmon Resonance. ACS Nano, 4, 5453-5463. https://doi.org/10.1021/nn101493t

[27] Oh, J., Chang, Y.W., Kim, H.J., Yoo, S., Kim, D.J., Im, S., Park, Y.J., Kim, D. and Yoo, K.-H. (2010) Carbon Nanotube-Based Dual-Mode Biosensor for Electrical and Surface Plasmon Resonance Measurements. Nano Letters, 10, 2755-2760. https://doi.org/10.1021/nl100125a

[28] Liu, H., Wang, B., Leong, E., Yang, P., Zong, Y., Si, G.Y., Teng, J. and Maier, S. (2010) Enhanced Surface Plasmon Resonance on a Smooth Silver Film with a Seed Growth Layer. ACS Nano, 4, 3139-3146. https://doi.org/10.1021/nn100466p

[29] Jain, P., Huang, X.H., El-Sayed, I. and El-Sayed, M. (2008) Noble Metals on the Nanoscale: Optical and Photothermal Properties and Some Applications in Imaging, Sensing, Biology, and Medicine. Accounts of Chemical Research, 41, 1578-1586. https://doi.org/10.1021/ar7002804

[30] Skrabalak, S.E., Chen, J.Y., Sun, Y.G., Lu, X.M., Au, L., Cobley, C. and Xia, Y.N. (2008) Gold Nanocages: Synthesis, Properties, and Applications. Accounts of Chemical Research, 41, 1587-1595. https://doi.org/10.1021/ar800018v

[31] Daniel, M.-C. and Astruc, D. (2004) Gold Nanoparticles: Assembly, Supramolecular Chemistry, Quantum-Size-Related Properties, and Applications toward Biology, Catalysis, and Nanotechnology. Chemical Reviews, 104, 293-346. https://doi.org/10.1021/cr030698+

[32] Zhao, J., Pinchuk, A., McMahon, J.M., Li, S.Z., Ausman, L.K., Atkinson, A.L. and Schatz, G.C. (2008) Methods for Describing the Electromagnetic Properties of Silver and Gold Nanoparticles. Accounts of Chemical Research, 41, 1710-1720. https://doi.org/10.1021/ar800028j

[33] Brus, L. (2008) Noble Metal Nanocrystals: Plasmon Electron Transfer Photochemistry and Single-Molecule Raman Spectroscopy. Accounts of Chemical Research, 41, 1742-1749. https://doi.org/10.1021/ar800121r

[34] Wang, X.C., Yu, J.C., Yip, H.Y., Wu, L., Po, K.W. and Lai, S.Y. (2005) A Mesoporous $\mathrm{Pt} / \mathrm{TiO}_{2}$ Nanoarchitecture with Catalytic and Photocatalytic Function. Chemistry-A European Journal, 11, 2997-3004. https://doi.org/10.1002/chem.200401248

[35] Wang, Q., Wen, Z.H. and Li, J. H. (2006) A Hybrid Supercapacitor Fabricated with a Carbon Nanotube Cathode and $\mathrm{TiO}_{2}-\mathrm{B}$ Nanowire Anode. Advanced Functional Materials, 16, 2141-2146. https://doi.org/10.1002/adfm.200500937

[36] Ibhadon, A. and Fitzpatrick, P. (2013) Heterogeneous Photocatalysis: Recent Ad- 
vances and Applications. Catalysts, 3, 189-218. https://doi.org/10.3390/catal3010189

[37] Chong, M., Jin, B., Chow, C. and Saint, C. (2010) Recent Developments in Photocatalytic Water Treatment Technology: A Review. Water Research, 44, 2997-3027. https://doi.org/10.1016/j.watres.2010.02.039

[38] Masschelin, W. and Rice, R. (2002) Ultraviolet Light in Water and Wastewater Sanitation. Lewis Publishers, Boca Raton.

[39] Li, F. and Li, X. (2002) The Enhancement of Photodegradation Efficiency Using Pt- $\mathrm{TiO}_{2}$ Catalyst. Chemosphere, 48, 1103-1111. https://doi.org/10.1016/S0045-6535(02)00201-1

[40] Ni, M., Leung, M., Leung, D. and Sumathy, K. (2007) A Review and Recent Developments in Photocatalytic Water-Splitting Using $\mathrm{TiO}_{2}$ for Hydrogen Production. Renewable \& Sustainable Energy Reviews, 11, 401-425. https://doi.org/10.1016/j.rser.2005.01.009

[41] Sun, Y. and Pignatello, J. (1995) Evidence for a Surface Dual Hole-Radical Mechanism in the $\mathrm{TiO}_{2}$ Photocatalytic Oxidation of 2,4-Dichlorophenoxyacetic Acid. Environmental Science \& Technology, 29, 2065-2072.

https://doi.org/10.1021/es00008a028

[42] Rabani, J., Yamashita, K., Ushida, K., Stark, J. and Kira, A. (1998) Fundamental Reactions in Illuminated Titanium Dioxide Nanocrystallite Layers Studied by Pulsed Laser. The Journal of Physical Chemistry B, 102, 1689-1695. https://doi.org/10.1021/jp973411j

[43] Chen, Y., Yang, S., Wang, K. and Lou, L. (2005) Role of Primary Active Species and $\mathrm{TiO}_{2}$ Surface Characteristic in UV-Illuminated Photodegradation of Acid Orange 7. Journal of Photochemistry and Photobiology A: Chemistry, 172, 47-54. https://doi.org/10.1016/j.jphotochem.2004.11.006

[44] Turchi, C. and Ollis, D. (1990) Photocatalytic Degradation of Organic-Water Contaminants-Mechanisms Involving Hydroxyl Radical Attack. Journal of Catalysis, 122, 178-192. https://doi.org/10.1016/0021-9517(90)90269-P

[45] Sakai, H., Baba, R., Hashimoto, K., Fujishima, A. and Heller, A. (1995) Local Detection of Photoelectrochemically Produced $\mathrm{H}_{2} \mathrm{O}_{2}$ with a Wired Horseradish-Peroxidase Microsensor. The Journal of Physical Chemistry, 99, 11896-11900.

https://doi.org/10.1021/j100031a017

[46] Kikuchi, Y., Sunada, K., Iyoda, T., Hashimoto, K. and Fujishima, A. (1997) Photocatalytic Bactericidal Effect of $\mathrm{TiO}_{2}$ Thin Films: Dynamic View of the Active Oxygen Species Responsible for the Effect. Journal of Photochemistry and Photobiology A: Chemistry, 106, 51-56. https://doi.org/10.1016/S1010-6030(97)00038-5

[47] Ranjit, K., Willner, I., Bossmann, S. and Braun, A. (2001) Lanthanide Oxide-Doped Titanium Dioxide Photocatalysts: Novel Photocatalysts for the Enhanced Degradation of p-Chlorophenoxyacetic Acid. Environmental Science \& Technology, 35, 1544-1549. https://doi.org/10.1021/es001613e

[48] Cho, M., Chung, H., Choi, W. and Yoon, J. (2004) Linear Correlation between Inactivation of $E$. coli and $\mathrm{OH}$ Radical Concentration in $\mathrm{TiO}_{2}$ Photocatalytic Disinfection. Water Research, 38, 1069-1077. https://doi.org/10.1016/j.watres.2003.10.029

[49] Rincon, A. and Pulgarin, C. (2004) Effect of pH, Inorganic Ions, Organic Matter and $\mathrm{H}_{2} \mathrm{O}_{2}$ on $E$. coli $\mathrm{K} 12$ Photocatalytic Inactivation by $\mathrm{TiO}_{2}$-Implications in Solar Water Disinfection. Applied Catalysis B: Environmental, 51, 283-302. https://doi.org/10.1016/j.apcatb.2004.03.007

[50] Serpone, N. (2006) Is the Band Gap of Pristine $\mathrm{TiO}_{2}$ Narrowed by Anion- and Ca- 
tion-Doping of Titanium Dioxide in Second-Generation Photocatalysts? The Journal of Physical Chemistry B, 110, 24287-24293. https://doi.org/10.1021/jp065659r

[51] Sunada, K., Kikuchi, Y., Hashimoto, K. and Fujishima, A. (1998) Bactericidal and Detoxification Effects of $\mathrm{TiO}_{2}$ Thin Film Photocatalysts. Environmental Science \& Technology, 32, 726-728. https://doi.org/10.1021/es970860o

[52] Booshehri, A., Goh, S., Hong, J., Jiang, R. and Xu, R. (2014) Effect of Depositing Silver Nanoparticles on $\mathrm{BiVO}_{4}$ in Enhancing Visible Light Photocatalytic Inactivation of Bacteria in Water. Journal of Materials Chemistry A, 2, 6209-6217. https://doi.org/10.1039/C3TA15392D

[53] Wang, P., Huang, B.B., Dai, Y. and Whangbo, M.-H. (2012) Plasmonic Photocatalysts: Harvesting Visible Light with Noble Metal Nanoparticles. Physical Chemistry Chemical Physics: PCCP, 14, 9813-9825. https://doi.org/10.1039/c2cp40823f

[54] Gordon, R., Sinton, D., Kavanagh, K.L. and Brolo, A. (2008) A New Generation of Sensors Based on Extraordinary Optical Transmission. Accounts of Chemical Research, 41, 1049-1057. https://doi.org/10.1021/ar800074d

[55] Kelly, K.L., Coronado, E., Zhao, L.L. and Schatz, G.C. (2003) The Optical Properties of Metal Nanoparticles: The Influence of Size Shape and Dielectric Environment. The Journal of Physical Chemistry B, 107, 668-677. https://doi.org/10.1021/jp026731y

[56] Eustis, S. and El-Sayed, M. (2006) Why Gold Nanoparticles Are More Precious than Pretty Gold: Noble Metal Surface Plasmon Resonance and Its Enhancement of the Radiative and Nonradiative Properties of Nanocrystals of Different Shapes. Chemical Society Reviews, 35, 209-217. https://doi.org/10.1039/B514191E

[57] Atwater, H. and Polman, A. (2010) Plasmonics for Improved Photovoltaic Devices. Nature Materials, 9, 865. https://doi.org/10.1038/nmat2866

[58] Chen, X., Zheng, Z., Ke, X., Jaatinen, E., Xie, T., Wang, D., Guo, C., Zhao, J. and Zhu, H. (2010) Supported Silver Nanoparticles as Photocatalysts under Ultraviolet and Visible Light Irradiation. Green Chemistry, 12, 414-419. https://doi.org/10.1039/b921696k

[59] Bohren, C. and Huffman, D. (1983) Absorption and Scattering of Light by Small Particles. Wiley, New York, 290-291.

[60] Barnes, W.L., Dereux, A. and Ebbesen, T.W. (2003) Surface Plasmon Subwavelength Optics. Nature, 424, 824-830. https://doi.org/10.1038/nature01937

[61] Kreibig, U. (1995) Optical Properties of Metal Clusters. Springer, Berlin, 25. https://doi.org/10.1007/978-3-662-09109-8

[62] Kochuveedu, S., Jang, Y. and Kim, D. (2013) A Study on the Mechanism for the Interaction of Light with Noble Metal-Metal Oxide Semiconductor Nanostructures for Various Photophysical Applications. Chemical Society Reviews, 42, 8467-8493. https://doi.org/10.1039/c3cs60043b

[63] Sarina, S., Waclawik, E.R. and Zhu, H. (2013) ChemInform Abstract: Photocatalysis on Supported Gold and Silver Nanoparticles under Ultraviolet and Visible Light Irradiation. Green Chemistry, 15, 1814-1833. https://doi.org/10.1039/c3gc40450a

[64] Tian, Y. and Tatsuma, T. (2005) Mechanisms and Applications of Plasmon-Induced Charge Separation at $\mathrm{TiO}_{2}$ Films Loaded with Gold Nanoparticles. Journal of the American Chemical Society, 127, 7632-7637. https://doi.org/10.1021/ja042192u

[65] Yu, K., Tian, Y. and Tatsuma, T. (2006) Size Effects of Gold Nanoparticles on Plasmon-Induced Photocurrents of Gold- $\mathrm{TiO}_{2}$ Nanocomposites. Physical Chemistry Chemical Physics. PCCP, 8, 5417-5420. https://doi.org/10.1039/B610720F 
[66] Furube, A., Du, L., Hara, K., Katoh, R. and Tachiya, M. (2008) Ultrafast Plasmon-Induced Electron Transfer from Gold Nanodots into $\mathrm{TiO}_{2}$ Nanoparticles. Journal of the American Chemical Society, 129, 14852-14853. https://doi.org/10.1021/ja076134v

[67] Zaleska, A. (2008) Doped- $\mathrm{TiO}_{2}$ : A Review. Recent Patents on Engineering, 2, 157-164. https://doi.org/10.2174/187221208786306289

[68] Kowalska, E., Remita, H., Colbeau-Justin, C., Jan, H. and Belloni, J. (2008) Modification of Titanium Dioxide with Platinum Ions and Clusters: Application in Photocatalysis. Journal of Physical Chemistry C, 112, 1124-1131. https://doi.org/10.1021/jp077466p

[69] Wu, X.-F., Song, H.-Y., Yoon, J.-M., Yu, Y.-T. and Chen, Y.-F. (2009) Synthesis of Core-Shell Au@ $\mathrm{TiO}_{2}$ Nanoparticles with Truncated Wedge-Shaped Morphology and Their Photocatalytic Properties. Langmuir, 25, 6438-6447. https://doi.org/10.1021/la900035a

[70] Ma, J., Xiong, Z., Waite, T., Ng, W. and Zhao, X. (2011) Enhanced Inactivation of Bacteria with Silver-Modified Mesoporous $\mathrm{TiO}_{2}$ under Weak Ultraviolet: Irradiation. Microporous and Mesoporous Materials, 144, 97-104. https://doi.org/10.1016/j.micromeso.2011.03.040

[71] Wang, X., Tang, Y., Chen, Z. and Lim, T. (2012) Highly Stable Heterostructure Ag-AgBr/TiO 2 Composite: A Bifunctional Visible-Light Active Photocatalyst for Destruction of Ibuprofen and Bacteria. Journal of Materials Chemistry, 22, 23149-23158. https://doi.org/10.1039/c2jm35503e

[72] Tsukamoto, D., Shiraishi, Y., Sugano, Y., Ichikawa, S., Tanaka, S. and Hirai, T. (2012) Gold Nanoparticles Located at the Interface of Anatase/Rutile $\mathrm{TiO}_{2}$ Particles as Active Plasmonic Photocatalysts for Aerobic Oxidation. Journal of the American Chemical Society, 134, 6309-6315. https://doi.org/10.1021/ja2120647

[73] Zheng, Z.F., Teo, J., Chen, X., Liu, H.W., Yuan, Y., Waclawik, E.R., Zhong, Z.Y. and Zhu, H. (2009) Correlation of the Catalytic Activity for Oxidation Taking Place on Various $\mathrm{TiO}_{2}$ Surfaces with Surface OFF Groups and Surface Oxygen Vacancies. Chemistry, 16, 1202-1211. https://doi.org/10.1002/chem.200901601

[74] Awazu, K., Fujimaki, M., Rockstuhl, C., Tominaga, J., Murakami, H., Ohki, Y., Yoshida, N. and Watanabe, T. (2008) A Plasmonic Photocatalyst Consisting of Silver Nanoparticles Embedded in Titanium Dioxide. Journal of the American Chemical Society, 130, 1676-1680. https://doi.org/10.1021/ja076503n

[75] Hu, C., Hu, X., Wang, L., Qu, J. and Wang, A. (2006) Visible-Light-Induced Photocatalytic Degradation of Azodyes in Aqueous $\mathrm{AgI} / \mathrm{TiO}_{2}$ Dispersion. Environmental Science Technology, 40, 7903-7907. https://doi.org/10.1021/es061599r

[76] Henle, J., Simon, P., Frenzel, A., Scholz, S. and Kaskel, S. (2007) Nanosized BiOX (X $=\mathrm{Cl}, \mathrm{Br}, \mathrm{I})$ Particles Synthesized in Reverse Microemulsions. Chemistry of Materials, 19, 366-373. https://doi.org/10.1021/cm061671k

[77] Zhang, X., Ai, Z., Jia, F. and Zhang, L. (2008) Generalized One-Pot Synthesis, Characterization, and Photocatalytic Activity of Hierarchical $\mathrm{BiOX}(\mathrm{X}=\mathrm{Cl}, \mathrm{Br}, \mathrm{I}) \mathrm{Na}-$ noplate Microspheres. The Journal of Physical Chemistry C, 112, 747-753. https://doi.org/10.1021/jp077471t

[78] Xia, J., Yin, S., Li, H., Xu, H., Yan, Y. and Zhang, Q. (2010) Self-Assembly and Enhanced Photocatalytic Properties of BiOI Hollow Microspheres via a Reactable Ionic Liquid. Langmuir, 27, 1200-1206. https://doi.org/10.1021/la104054r

[79] Li, Y., Wang, J., Yao, H., Dang, L. and Li, Z. (2011) Efficient Decomposition of Organic Compounds and Reaction Mechanism with BiOI Photocatalyst under Visible 
Light Irradiation. Journal of Molecular Catalysis A: Chemical, 334, 116-122. https://doi.org/10.1016/j.molcata.2010.11.005

[80] Zhang, L.S., Wong, K.-H., Yip, H.-Y., Hu, C., Yu, J.C., Chan, C.-Y. and Wong, P.-K. (2010) Effective Photocatalytic Disinfection of E. coli K-12 Using AgBr-Ag- $\mathrm{Bi}_{2} \mathrm{WO}_{6}$ Nanojunction System Irradiated by Visible Light: The Role of Diffusing Hydroxyl Radicals. Environmental Science Technology, 44, 1392-1398. https://doi.org/10.1021/es903087w

[81] Yu, C., Yu, J.C., Fan, C., Wen, H. and Hu, S. (2010) Synthesis and Characterization of Pt/BiOI Nanoplate Catalyst with Enhanced Activity under Visible Light Irradiation. Materials Science and Engineering: B, 166, 213-219. https://doi.org/10.1016/j.mseb.2009.11.029

[82] Bi, Y., Ouyang, S., Cao, J., et al. (2011) Facile Synthesis of Rhombic Dodecahedral $\mathrm{AgX} / \mathrm{Ag}_{3} \mathrm{PO}_{4}(\mathrm{X}=\mathrm{Cl}, \mathrm{Br}, \mathrm{I})$ Heterocrystals with Enhanced Photocatalytic Properties and Stabilities. Physical Chemistry Chemical Physics, 13, 10071-10075. https://doi.org/10.1039/c1cp20488b

[83] Tong, Z.W., Yang, D., Sun, Y.Y., et al. (2015) In Situ Fabrication of $\mathrm{Ag}_{3} \mathrm{PO}_{4} / \mathrm{TiO}_{2}$ Nanotube Heterojunctions with Enhanced Visible-Light Photocatalytic Activity. Physical Chemistry Chemical Physics, 17, 12199-12206. https://doi.org/10.1039/C4CP05851H

[84] Li, Y., Zhang, W., Niu, J.F. and Chen, Y.S. (2012) Mechanism of Photogenerated Reactive Oxygen Species and Correlation with the Antibacterial Properties of Engineered Metal-Oxide Nanoparticles. ACS Nano, 6, 5164-5173. https://doi.org/10.1021/nn300934k

[85] Zhu, L.F., He, C., Huang, Y.L., Chen, Z.H., Xia, D., Su, M.H., Xiong, Y., Li, S.Y. and Shu, D. (2011) Enhanced Photocatalytic Disinfection of E. coli 8099 Using Ag/BiOI Composite under Visible Light Irradiation. Separation and Purification Technology, 91, 59-66. https://doi.org/10.1016/j.seppur.2011.10.026

[86] Huang, T.-Y., Chen, Y.-J., Lai, C.-Y. and Lin, Y.-W. (2015) Synthesis, Characterization, Enhanced Sunlight Photocatalytic Properties, and Stability of $\mathrm{Ag} / \mathrm{Ag}_{3} \mathrm{PO}_{4} \mathrm{Na}$ nostructure-Sensitized $\mathrm{BiPO}_{4}$. RSC Advances, 5, 43854-43862. https://doi.org/10.1039/C5RA07101A

[87] Ren, J.W., Wang, W., Sun, S., Zhang, L. and Chang, J. (2009) Enhanced Photocatalytic Activity of $\mathrm{Bi}_{2} \mathrm{WO}_{6}$ Loaded with Ag Nanoparticles under Visible Light Irradiation. Applied Catalysis B: Environmental, 92, 50-55. https://doi.org/10.1016/j.apcatb.2009.07.022

[88] Liu, H., Li, D.R., Yang, X.L. and Li, H.F. (2018) Fabrication and Characterization of $\mathrm{Ag}_{3} \mathrm{PO}_{4} / \mathrm{TiO}_{2}$ Heterostructure with Improved Visible-Light Photocatalytic Activity for the Degradation of Methyl Orange and Sterilization of E. coli. Materials Technology, 34, 192-203. https://doi.org/10.1080/10667857.2018.1545391

[89] Hu, X.X., Hu, C., Peng, T.W., Zhou, X.F. and Qu, J.H. (2010) Plasmon-Induced Inactivation of Enteric Pathogenic Microorganisms with $\mathrm{Ag}-\mathrm{AgI} / \mathrm{Al}_{2} \mathrm{O}_{3}$ under Visible-Light Irradiation. Environmental Science \& Technology, 44, 7058-7062. https://doi.org/10.1021/es1012577

[90] Lan, Y.Q., Hu, C., Hu, X.X. and Qu, J.H. (2007) Efficient Destruction of Pathogenic Bacteria with $\mathrm{AgBr} / \mathrm{TiO}_{2}$ under Visible Light Irradiation. Applied Catalysis B-Environmental, 73, 354-360. https://doi.org/10.1016/j.apcatb.2007.01.004

[91] Yang, X.F., Qin, J.L., Jiang, Y., Li, R., Li, Y. and Tang, H. (2014) Bifunctional $\mathrm{TiO}_{2} / \mathrm{Ag}_{3} \mathrm{PO}_{4} /$ Graphene Composites with Superior Visible Light Photocatalytic Performance and Synergistic Inactivation of Bacteria. RSC Advances, 4, 18627-18636. 
https://doi.org/10.1039/C4RA01559B

[92] Liang, Q.H., Shi, Y., Ma, W.J., Li, Z. and Yang, X.M. (2012) Enhanced Photocatalytic Activity and Structural Stability by Hybridizing $\mathrm{Ag}_{3} \mathrm{PO}_{4}$ Nanospheres with Graphene Oxide Sheets. Physical Chemistry Chemical Physics. PCCP, 14, 10. https://doi.org/10.1039/c2cp42465g

[93] Sheu, F.-J., Cho, C.-P., Liao, Y.-T. and Yu, C.-T. (2018) $\mathrm{Ag}_{3} \mathrm{PO}_{4}-\mathrm{TiO}_{2}$-Graphene Oxide Ternary Composites with Efficient Photodegradation, Hydrogen Evolution, and Antibacterial Properties. Catalysts, 8, 57. https://doi.org/10.3390/catal8020057

[94] Chen, G.D., Sun, M., Wei, Q., Zhang, Y.F., Zhu, B.C. and Du, B. (2012) $\mathrm{Ag}_{3} \mathrm{PO}_{4} /$ Graphene-Oxide Composite with Remarkably Enhanced Visible-Light-Driven Photocatalytic Activity toward Dyes in Water. Journal of Hazardous Materials, 244-245, 86-93. https://doi.org/10.1016/j.jhazmat.2012.11.032

[95] Erkan, A., Bakir, U. and Karakas, G. (2006) Photocatalytic Microbial Inactivation over Pd Doped $\mathrm{SnO}_{2}$ and $\mathrm{TiO}_{2}$ Thin Films. Journal of Photochemistry and Photobiology A: Chemistry, 184, 313-321. https://doi.org/10.1016/j.jphotochem.2006.05.001

[96] Hu, C., Lan, Y.Q., Qu, J.H., Hu, X.X. and Wang, A.M. (2006) Ag/AgBr/TiO 2 Visible Light Photocatalyst for Destruction of Azodyes and Bacteria. The Journal of Physical Chemistry B, 110, 4066-4072. https://doi.org/10.1021/jp0564400

[97] Hu, C., Guo, J., Qu, J.H. and Hu, X.X. (2007) Photocatalytic Degradation of Pathogenic Bacteria with $\mathrm{AgI} / \mathrm{TiO}_{2}$ under Visible Light Irradiation. Langmuir. The ACS Journal of Surfaces and Colloids, 23, 4982-4987. https://doi.org/10.1021/la063626x

[98] Xu, J.-W., Gao, Z.-D., Han, K., Liu, Y.M. and Song, Y.-Y. (2014) Synthesis of Magnetically Separable $\mathrm{Ag}_{3} \mathrm{PO}_{4} / \mathrm{TiO}_{2} / \mathrm{Fe}_{3} \mathrm{O}_{4}$ Heterostructure with Enhanced Photocatalytic Performance under Visible Light for Photoinactivation of Bacteria. ACS Applied Materials, Interfaces, 6, 15122-15131. https://doi.org/10.1021/am5032727

[99] Ma, S.L., Zhan, S.H., Jia, Y.N., Shi, Q. and Zhou, Q.X. (2016) Enhanced Disinfection Application of Ag-Modified g-C3N4 Composite under Visible Light. Applied Catalysis B: Environmental, 186, 77-87. https://doi.org/10.1016/j.apcatb.2015.12.051

[100] Wang, P., Huang, B.B., Qin, X.Y., Zhang, X.Y., Dai, Y. and Whangbo, M.-H. (2009) $\mathrm{Ag} / \mathrm{AgBr} / \mathrm{WO}_{3}$ Center Dot $\mathrm{H}_{2} \mathrm{O}$ : Visible-Light Photocatalyst for Bacteria Destruction. Inorganic Chemistry, 48, 10697-10702. https://doi.org/10.1021/ic9014652

[101] Cheng, H.F., Huang, B.B., Wang, P., Wang, Z.Y., Lou, Z.Z., Wang, J.P., Qin, X.Y., Zhang, X.Y. and Dai, Y. (2011) In Situ Ion Exchange Synthesis of the Novel $\mathrm{Ag} / \mathrm{AgBr} / \mathrm{BiOBr}$ Hybrid with Highly Efficient Decontamination of Pollutants. Chemical Communications, 47, 7054-7056. https://doi.org/10.1039/c1cc11525a

[102] Hu, C., Peng, T., Hu, X., Nie, Y., Zhou, X., Qu, J. and He, H. (2009) Plasmon-Induced Photodegradation of Toxic Pollutants with Ag-AgI/ $\mathrm{Al}_{2} \mathrm{O}_{3}$ under Visible-Light Irradiation. Journal of the American Chemical Society, 132, 857-862. https://doi.org/10.1021/ja907792d

[103] Xu, B., Xiao, T., Yan, Z., Sun, X., Sloan, J., González-Cortés, S., Alshahrani, F. and Green, M.L.H. (2006) Synthesis of Mesoporous Alumina with Highly Thermal Stability Using Glucose Template in Aqueous System. Microporous and Mesoporous Materials, 91, 293-295. https://doi.org/10.1016/j.micromeso.2005.12.007

[104] Zhang, Z., Ma, Y., Bu, X., Wu, Q., Hang, Z., Dong, Z. and Wu, X. (2018) Facile One-Step Synthesis of $\mathrm{TiO}_{2} / \mathrm{Ag} / \mathrm{SnO}_{2}$ Ternary Heterostructures with Enhanced Visible Light Photocatalytic Activity. Scientific Reports, 8, Article No. 10532. https://doi.org/10.1038/s41598-018-28832-w 